\title{
Multi-level Administration, Inspections and Fundamental Rights: Is Judicial Protection Full and Effective?
}

\author{
Maurizia De Bellis* \\ Public Law Department, University of Rome, Rome, Italy \\ Corresponding author: Maurizia De Bellis, Email: maurizia.debellis@gmail.com
}

(Received 29 March 2021; accepted 11 April 2021)

\begin{abstract}
In the last decades, an increasing number of $\mathrm{EU}$ institutions and agencies have been given the power to conduct administrative inspections. While the legal literature has traditionally focused on the Commission's inspection powers in competition proceedings, the European Anti-Fraud Office (OLAF), the European Central Bank (ECB), the European Securities and Markets Authority (ESMA), the European Aviation Safety Agency (EASA), and the European Fisheries Control Agency (EFCA) are also entrusted with such powers. The Commission has also been granted inspection powers in the field of Food Safety. Inspection powers can have a crucial impact on the fundamental right of the inviolability of the home, recognized by the Court of Justice as a general principle of EU law, and protected under Article 8 of the European Convention of Human Rights (ECHR) and Article 7 of the EU Charter of Fundamental Rights (ECFR). This Article argues that the current remedies do not fulfill all the criteria set forth by the Strasbourg Court for ex post judicial control vis-à vis inspections to be full and effective, in particular when these powers are used in the context of composite procedures, and suggests remedies to improve the system of review, in order to effectively protect fundamental rights.
\end{abstract}

Keywords: inspection; enforcement; EU agencies; fundamental rights; judicial review

\section{A. Introduction}

In the last decade, EU direct enforcement has been increasing. ${ }^{1}$ Of the three enforcement activities that can be traced-for example, monitoring, investigating, and sanctioning violations ${ }^{2}$ - this Article examines the second, and, more specifically, inspection powers. According to a study from the Organization for Economic Co-operation and Development (OECD), inspections can be defined as "any type of visit or check conducted by authorized officials on products or business premises, activities, documents etc."3

\footnotetext{
*Tenured Assistant Professor, University of Rome “Tor Vergata.” (maurizia.debellis@gmail.com)

${ }^{1}$ The most recent and comprehensive analysis of direct enforcement by EU authorities is LAW ENFORCEMENT BY EU Authorities: Implications for Political and Judicial Accountability (Miroslava Scholten \& Michiel Luchtman eds., 2017) [hereinafter LAW ENFORCEMENT By EU AUTHORITIEs].

${ }^{2}$ See Miroslava Scholten, Michiel Luchtman \& Elmar Schmidt, The Proliferation of EU Enforcement Authorities: A New Development in Law Enforcement in the EU, in LAw ENFORCEMENT BY EU AUTHORITIES, supra note 1, at 1, 4-5.

${ }^{3}$ Organisation for Economic Co-operation and Development, Regulatory Enforcement and Inspections, 11 (2014). 
Inspection powers can have a crucial impact on the fundamental right of the inviolability of the home. ${ }^{4}$ This right has been recognized by the Court of Justice as a general principle of EU law, and also derives from Article 8 of the European Convention of Human Rights (ECHR) and Article 7 of the EU Charter of Fundamental Rights (ECFR), the right to private life. ${ }^{5}$ Moreover, when involving the investigations of documents, in a context where dematerialization is increasingly the rule, inspections often impair the privacy of communications. This can be the case when EU inspectors take copies of hard disks and emails.

In this context, this Article seeks to address two main questions: What are the conditions for the public intervention intrusion on fundamental rights to be lawful? Does the system of judicial control on the inspection powers of EU authorities meet these conditions?

The constitutions of EU Member States usually devote separate provisions to the protection of the inviolability of the home and the privacy of communications. However, the system of protection of these rights is similar, requiring that inspection powers are provided for in the law and-in some national constitutional traditions - that ex ante judicial authorization is in place. The ECHR and the ECFR, both protecting the right to privacy and all the interests connected with it under one single provision, do not explicitly mention the features of judicial control on public intervention on such a fundamental right. On the contrary, they focus on the need for such intrusion to be proportionate to pursue a legitimate aim. However, both the Court of Luxembourg and the Court of Strasbourg have examined the features of judicial control on inspections in the context of the proportionality test and as stemming from Articles 47 of the ECFR and Article 6 of the ECHR.

The Court of Justice has been repeatedly requested to verify whether inspection powers infringed the fundamental rights of the inspected entities in the competition area. ${ }^{6}$ This is due to the fact that the Commission has been entrusted with this type of power in such areas since the 1960s. ${ }^{7}$ In particular, since the Roquettes case, the Court of Justice clarified that EU law does not require ex ante judicial authorization for inspections to be lawful and that, when domestic laws require such preventive control, national judges can only verify that such measures are not arbitrary or disproportionate, but cannot review their justification. ${ }^{8}$ The necessity and lawfulness of the decision to inspect fall in the sole jurisdiction of the Court of Justice. The results of the EU Court case law have been codified in Regulation 1/2003. ${ }^{9}$

According to Advocate General Wagner in the Deutsche Bahn case, the scope of national judges' preventive scrutiny, as circumscribed by the Court and codified in the Regulation, is so limited that it is very unlikely that the national authorization can be denied. ${ }^{10}$ The Court of

\footnotetext{
${ }^{4}$ See Jean-Bernard Auby, I poteri ispettivi dell'Unione europea, 2 RIVISTA TRIMESTRALE DI DIRITTO PUBbLICO 353 (2006). In the Italian legal literature, see 2 Massimo Severo Giannini, Diritto amministrativo 488 (1993); Stelio Valentini, Le ISPEZIONI AMMINISTRATIVE (1971).

${ }^{5}$ On Article 8 of the ECHR, see David Harris, Michael O'Boyle, Edward Bates \& Carla Buckley, Law of the European Convention on Human Rights, 522 (3d ed., Oxford Univ. Press 2014). About the correspondence of Article 8 ECHR and Article 7 of the ECFR, see infra, Section C.

${ }^{6}$ On criticisms concerning inspections in the competition area, see ARIANNA ANDREANGELI, EU COMPETITION Enforcement and Human Rights 31 (2008); Giacinto della Cananea, The European Union and the "Legitimate Use of Force": Administrative Inspections and Legal Safeguards, in THE NATURE OF INQUisitorIAL Processes IN Administrative Regimes 167 (Laverne Jacobs \& Sasha Baglay eds., 2013).

${ }^{7}$ Council Regulation 17/62 of Feb. 6, 1962, First Regulation Implementing Articles 85 and 86 of the Treaty, art. 14, 1962 O.J. 13, 204 (EC).

${ }^{8}$ Case C-94/00, Roquette Frères SA v. Directeur général de la concurrence, de la consommation et de la répression des fraudes, and Commission, 2002 E.C.R. I-09011, para. 99.

${ }^{9}$ Council Regulation $1 / 2003$ of 16 Dec. 16, 2002, On the Implementation of the Rules on Competition Laid Down in Articles 81 and 82 of the Treaty, art. 20, para. 8, 2003 O.J. (L 001) 1 (EC).

${ }^{10}$ Opinion of Advocate General Wahl, Case C-583/13P, Deutsche Bahn v. Comm'n, 2015 E.C.R. 20 http://curia.europa.eu/ juris/liste.jsf?num=C-583/13.
} 
Justice has consistently claimed that the lack of an ex ante judicial control is counterbalanced by a comprehensive post-inspection review covering both questions of fact and questions of law. ${ }^{11}$ As a result, the features of ex post judicial scrutiny on inspection powers are crucial for the lawfulness of such intrusive prerogatives.

Ex ante judicial control is considered for inspection powers to be lawful under some national constitutional traditions, as it can prevent unlawful intrusions on the right of the inviolability of the home. This view is shared by the Court of Strasbourg, which takes into account the existence of preventive judicial control in assessing whether a public intrusion on the inviolability of the home is proportionate. As this instrument is lacking or limited when such powers are used in the context of multi-level administration, it is essential to find instruments that can ensure that the intrusion respects the right of the defense of the inspected entities during the inspection procedure. For example, that no privileged document is seized-and that, should an unlawful intrusion take place, judicial remedies that can ex post effectively restore the inspected party's rights are in place. A full discussion of the procedural guarantees to be respected during the inspections fall outside the scope of this Article. Instead, this Article will focus on the instruments for judicial control. It will argue, on the one hand, that, notwithstanding the fact that the EU Court of Justice claims that its case law is in line with that of the Strasbourg Court, the latter provides a much stricter interpretation of the conditions upon which the lack of preventive judicial control can be compensated than through an ex post one. On the other hand, this Article claims that current ex post judicial remedies do not fulfill all the criteria set forth by the Strasbourg Court for ex post judicial control vis-à vis inspections to be full and effective.

This Article proceeds as follows. First, Section B analyzes the scope of inspection powers given to EU authorities. Second, Section C clarifies the requirements according to which the public interference on the fundamental right to the inviolability of the home is unlawful under national Constitutions, under the EU Charter of Fundamental Rights, and under the ECHR. Third, Section D explores what are the features of judicial control on inspections according to the Court of Justice and to the Strasbourg Court, showing that the two Courts set forth different conditions that need to be met in order to compensate for the lack of ex ante judicial authorization. Fourth, in Section E, the Article will claim that current remedies fall short in providing a full ex post judicial scrutiny, in particular when these powers are used in the context of composite procedures. Section F concludes, suggesting remedies to improve the effective protection of fundamental rights vis-à-vis inspection powers in the context of multi-level administration.

\section{B. The Scope and the Functioning of EU Inspection Powers}

Over the last fifteen years, several European administrations have been given powers of inspection. The analysis will divide the inspection powers of EU authorities into two groups.

In the first group of sectors-competition, financial, and aviation-not only are inspection powers given to EU authorities, but also the sanctioning powers that can be activated based on the results of such inspections. ${ }^{12}$ In the second group of cases, though, the inspecting authorities are not competent for adopting the final sanction, so that a mixed, top-down procedure takes

\footnotetext{
${ }^{11}$ Joined Cases T-289, T-290 \& T-521/11, Deutsche Bahn v. Comm'n, ECLI:EU:T:2013:404, (Sept. 6, 2013), para. 74, http:// curia.europa.eu/juris/liste.jsf?num=T-289/11; Case C-583/13 P, Deutsche Bahn v. Comm'n, ECLI:EU:C:2015:404, (June 18, 2015), para. 26, http://curia.europa.eu/juris/liste.jsf?num=C-583/13.

${ }^{12}$ However, while in the financial sector the European Securities and Markets Authority (ESMA), can execute both inspecting and sanctioning powers, in the area of aviation the European Aviation Safety Agency (EASA) conducts inspections. The Commission retains the sanctioning powers. See infra Section B.
} 
place. ${ }^{13}$ This is the case of the European Anti-Fraud Office (OLAF), the European Fisheries Control Agency (EFCA), and the Commission in the area of Food Safety. In the banking sector, both scenarios can emerge, as the European Central Bank (ECB), which conducts inspections on significant credit institutions through mixed teams, can decide on sanctions or can ask national authorities to start a sanctioning proceeding according to a complex system of division of competences. ${ }^{14}$ In the second group of cases, as well as when ECB inspections result in sanctions from National Competent Authorities (NCAs), the establishment of a system of effective judicial protection for the inspected parties is particularly challenging as inspection reports-which serve as preparatory acts in the decision-making process and lack any binding legal effect-are generally considered non-reviewable in annulment actions under Article 263 TFEU. ${ }^{15}$

As mentioned above, the first group includes the competition, banking, financial, and aviation sectors. It is widely known that competition is the area where inspection powers have long been established: The powers of inspection of the Commission were provided for by Regulation No. 17/ 62 and broadened in Regulation No. 1/2003. ${ }^{16}$ Within the latter, the division of labor between the Commission and the NCAs, which are part of the European Competition Network (ECN), follow the criteria of parallel competences. ${ }^{17}$ The scope and functioning of inspection powers in the competition field have clearly been used as a template for the inspection powers assigned to the ECB and the European Securities and Markets Authority (ESMA) following the global financial crisis of 2008. Within the Single Supervisory Mechanism (SSM), the first of the pillars of the European Banking Union (EBU), the Supervisory Committee of the ECB is responsible for overseeing credit institutions in eurozone Member States whose importance is "significant," according to parameters concerning the size and propensity of risk of the operators. Below this threshold, competence lies with the national authorities. ${ }^{18}$ ESMA, an EU agency, over time has been assigned direct

\footnotetext{
${ }^{13}$ On composite or mixed procedures, see, for example, Giacinto Della Cananea, The European Union's Mixed Administrative Proceedings, 68 L. \& Contemp. Probs. 197 (2004); Sabino Cassese, European Administrative Proceedings, 68 L. \& Contemp. Probs. 21 (2004); The European Composite Administration (Oswald Jansen \& Bettina SchöndorfHaubold eds., 2011); Herwig C.H. Hofmann, Composite Decision Making Procedures in EU Administrative Law, in LEGAL Challenges in EU Administrative Law: Towards an Integrated Administration 136 (Herwig C.H. Hofmann \& Alexander H. Türk eds., 2009); Mariolina Eliantonio, Judicial Review in an Integrated Administration: The Case of 'Composite Procedures', 7 Rev. Eur. Admin. L. 65 (2014); Filipe Brito Bastos, Derivative Illegality in European Composite Administrative Procedures, 55 Common Mkt. L. Rev. 101 (2018); Sergio Alonso de León, Composite administrative procedures in the European Union 251-318 (2017); Christina Eckes \& Joana Mendes, The Right to Be Heard in Composite Administrative Procedures: Lost in Between Protection?, 36 Eur. L. Rev. 651 (2011).

${ }^{14}$ Council Regulation 1024/2013 of Oct. 15, 2013, Conferring Specific Tasks to the European Central Bank Regarding Policies Relating to the Prudential Supervision of Credit Institutions, art. 18, 2013 O.J. (L 287) 63 [hereinafter SSM Regulation]; European Central Bank Regulation 468/2014 of Apr. 16, 2014, Establishing the Framework for Cooperation Within the Single Supervisory Mechanism between the European Central Bank and National Competent Authorities and with National Designated Authorities, art. 134, 2014 O.J. (L 141) 1 [hereinafter SSM Framework Regulation].

For a comment on the division of sanctioning competences, see Stefaan Loosveld, The ECB's Investigatory and Sanctioning Powers under the Future Single Supervisory Mechanism, 28 J. INT'L BANKING L. REG. 423 (2013); Klaus Lackhoff, How Will the Single Supervisory Mechanism (SSM) Function?, 29 J. INT'L BANKING L. REG. 20, 25-26 (2014); Silvia Allegrezza \& Olivier Voordeckers, Investigative and Sanctioning Powers of the ECB in the Framework of the Single Supervisory Mechanism Mapping the Complexity of a New Enforcement Model, 4/2015 EuCRIM 151, 156-57 (2015).

${ }^{15}$ Rob Widdershoven \& Paul Craig, Pertinent Issues of Judicial Accountability in Shared Enforcement, in LAW ENForCEMENT By EU Authorities, supra note 1, at 330, 348. See also infra Section E.

${ }^{16}$ Council Regulation 17/62 of Feb. 6, 1962, First Regulation Implementing Articles 85 and 86 of the Treaty, art. 14, 1962 O.J. 13, 204; Council Regulation 1/2003, supra note 9, at art. 20-1.

${ }^{17}$ EC Commission, Commission Notice on Cooperation Within the Network of Competition Authorities, 2004 O.J. (C 101) 43, para. 6-9. For this criteria, Paul Craig, EU Administrative Law, 74 (2d ed. 2012); Alexander H. Türk, Modernisation of EC Antitrust Enforcement, in EU Administrative Governance, 216-17 (Herwig C.H. Hofmann \& Alexander H. Türk eds., 2006).

${ }^{18} \mathrm{SSM}$ Regulation, supra note 14 , at art. 12. On the EBU, the literature is widespread. Among the most recent comprehensive books, see The Palgrave Handbook of European Banking Union Law (Mario Pilade Chiti \& Vittorio Santoro eds., 2019); The European Banking Union AND the Role of LAW (Gianni Lo Schiavo ed., 2019).
} 
supervisory and control powers, including powers of inspection, ${ }^{19}$ with respect to only some specific operators, such as credit rating agencies (CRAs), ${ }^{20}$ trade repositories (TRs), central clearing counterparts of third countries (CCP), ${ }^{21}$ and other providers of financial information. ${ }^{22}$ Within this first group, the European Aviation Safety Agency (EASA) ${ }^{23}$ can also be considered, even though there are some differences. ${ }^{24}$ For example, this agency can carry out inspections on both undertakings and "monitoring" of Member States competent authorities. ${ }^{25}$ EASA can act as an "inspector of inspectors." 26

The inspecting powers of the Commission, of the ECB, the ESMA, and the EASA include: a) access to the premises of the companies, banks, financial operators, and lands or means of transport, respectively; b) checking the documents and any other relevant material; c) making copies of such documents and materials; and d) asking for written and oral explanations. ${ }^{27}$ However, while in the banking, financial, and aviation areas access is restricted to the professional premises, in the competition area, the inspectors can also access the residence of the managers, directors, or other members of the company staff - a novelty introduced in 2003. Moreover, in the competition and the financial areas, the inspectors can seal the premises and company documents for the duration of the investigations to the extent necessary for their completion. ${ }^{28}$ Comparatively, in the case of bank inspections, this power stays in the domain of the national competent authority, and in the

\footnotetext{
${ }^{19}$ Niamh Moloney, The European Securities and Markets Authority and Institutional Design for the EU Financial Market A Tale of Two Competences: Part (1) Rule Making, 12 EUBOR 41 (2011); Niamh Moloney, The European Securities and Markets Authority and Institutional Design for the EU Financial Market - A Tale of Two Competences: Part (2) Rules in Action, 12 EUBOR 177 (2011); László Szegedi, Challenges of Direct European Supervision of Financial Markets, 57 PUB. FIN. Q. 347 (2012); Miroslava Scholten \& Annetje Ottow, Institutional Design of Enforcement in the EU: The Case of Financial Markets, 10 Utrecht L. Rev. 80 (2014).

${ }^{20}$ Regulation 513/2011, of the European Parliament and of the Council of 11 May 2011 Amending Regulation 1060/2009 Concerning Rating Agencies, art. 23d, para. 1, 2011 O.J. (L 145) 30, [hereinafter Regulation CRA].

${ }^{21}$ Regulation 648/2012, of the European Parliament and of the Council of 4 July 2012 on OTC Derivative Instruments, Central Counterparties and Trade Repositories on Negotiations, arts. 25e, 25h \& 63, 2012 O.J. (L 201), 1 [hereinafter Regulation Emir].

${ }^{22}$ Inspection powers on data reporting service providers (DRSPs) and critical benchmarks have been attributed to Regulation of the European Parliament and of the Council of 15 May 2014 on Markets in Financial Instruments and Amending Regulation 648/2012, arts. 38b-38d, 2014 O.J. (L 173) 84; Regulation 2016/1011 of the European Parliament and of the Council of 8 June 2016 on Indices Used as Benchmarks in Financial Instruments and Financial Contracts or to Measure the Performance of Investment Funds and Amending Directives 2008/48/EC and 2014/17/EU and Regulation 596/2014, art. 40, para. 1, 2016 O.J. (L 171) 1 (amended by European Parliament and Council Regulation 2019/2175 of 18 December 2019, 2019 O.J. (L 334) 1).

${ }^{23}$ Council Regulation 1592/2002 of 15 July 2002 on Common Rules in the Field of Civil Aviation and Establishing a European Aviation Safety Agency, 2002 O.J. (L 240) 1.

${ }^{24}$ For a general overview of EASA, see Florin Coman-Kund, Mikołaj Ratajczyk \& Elmar Schmidt, Shared Enforcement and Accountability in the EU Aviation Safety Area: The Case of the European Aviation Safety Agency, in LAW ENFORCEMENT BY EU AUTHORITIES, supra note 1 , at 115-17.

${ }^{25}$ Regulation 2018/1139 of the European Parliament and of the Council of 4 July 2018 on Common Rules in the Field of Civil Aviation and Establishing a European Union Aviation Safety Agency, and Amending Regulations 2111/2005, 1008/2008, 996/2010, 376/2014 and Directives 2014/30/EU and 2014/53/EU, and Repealing Regulations 552/2004 and 216/2008 and Council Regulation 3922/91, art. 83, para. 2, and art. 85, 2018 O.J. (L 212) 1. For a first comment, see Marta Simoncini, The Rulemaking Function of the European Aviation Safety Agency (EASA), in EU ExeCUTIVe GovernanCE: Agencies AND Procedures (Martina Conticelli, Maurizia De Bellis \& Giacinto Della Cananea eds., 2019).

${ }^{26}$ Adriaan Schout, Inspecting Aviation Safety in the EU: EASA as an Administrative Innovation?, in EUROPEAN RISK GOVERnANCE: ITS SCIENCE, ITS INCLUSIVENESS AND ITS EFFECTIVENESS, CONNEX Report Series No. 6, 257, 267-68 (2007).

${ }^{27}$ Regulation 1/2003, supra note 9, at art. 20, para. 1; SSM Regulation, supra note 14, at art. 12; Regulation CRA, supra note 20, at art. 23d, para. 1; Regulation Emir, supra note 20, at art. 63, para. 1; Regulation 2018/1139, supra note 25, at art. 83, para. 2 , and art. 85, para. 2. In this latter case, EASA can ask only for oral, not written explanations.

${ }^{28}$ Regulation 1/2003, supra note 9, at art. 20, par. 1; Regulation CRA, supra note 20, at art. 23d, para. 1; Regulation Emir, supra note 20 , at art. 63 , para. 1.
} 
case of aviation, this power is not mentioned. ${ }^{29}$ Further, the ESMA alone can request documentation also relating to telephone and data traffic. ${ }^{30}$

Regarding the substantial conditions for the activation of powers of inspection, all the regulations require that this has to be "necessary" for the functions attributed to EU authorities. In the case of competition home inspections, there must also be a reasonable suspicion that company records are kept on these premises and that these documents are relevant in proving a "serious" infringement of European competition law. ${ }^{31}$ In regard to the procedural conditions, in the competition and the financial sectors, inspections can be carried out either upon simple authorization or on the basis of a decision of the Commission or the ESMA, respectively; a decision of the ECB or the EASA is always necessary in the banking and aviation areas, and for domiciliary inspections in the competition area. ${ }^{32}$ The effects are different: Only when the inspection is decided with a decision, the recipients of the inspections are obliged to undergo inspection. If they refuse, they are subject to pecuniary penalties. ${ }^{33}$ Moreover, in case of opposition to an inspection ordered on the basis of a decision, the inspected entities can be obliged with the use of force. However, European officials do not have such power. In this event, the Member State has to provide the necessary assistance, employing the police or an equivalent authority. ${ }^{34}$

In the competition, banking, and financial sectors, the same EU authority has the power to inspect and, later on, to use the results gathered during the investigation to impose sanctions. However, as already mentioned, ${ }^{35}$ this is not always the case in the banking sector, as a complex division of sanctioning competences is established between the ECB and NCAs. ${ }^{36}$ In the area of aviation safety, the inspecting authority is not also the one competent for sanctions, as EASA does not itself decide on sanctions: It shall propose them to the Commission, that retains such competence. ${ }^{37}$ However, because the sanctioning authority is the Commission, the administrative procedure takes place entirely at the EU level.

In the four sectors examined so far, the decision to inspect is taken by an EU authority, which also performs the inspection activities. Moreover, an EU authority can also adopt sanctions on the basis of the results of the inspection. However, there are many instruments of collaboration between the EU inspecting authority and the authorities of the Member State in which the inspection is carried out. On the one hand, before the inspection, the EU authority has to notify or consult the national one in good time. ${ }^{38}$ On the other hand, in the investigation phase, the national authority is obliged to assist the EU. Such cooperation, as mentioned above, is crucial in case of opposition from the inspected entity. ${ }^{39}$ In these cases, national authorities play a supporting role

\footnotetext{
${ }^{29}$ SSM Regulation, supra note 20 , at art. 12 , para. 5 .

${ }^{30}$ Regulation CRA, supra note 20, at art. 23c, para. 1, and art. 23d, para. 2e; Regulation Emir, supra note 20, at art. 63, para. 2, and art. 62, para. 1e.

${ }^{31}$ Regulation $1 / 2003$, supra note 9 , at art. 21 , para. 1 .

${ }^{32} I d$., at art. 20, paras. 3-4, and art. 21, paras. 1-2; SSM Regulation, supra note 14, at art. 12, paras. 2-3 ; Regulation CRA, supra note 20, at art. 23d, paras. 3-4; Regulation Emir, supra note 20, at art. 63, paras. 2-4; Regulation 2018/1139, supra note 25 , at art. 76 , para. 2 , art. 83 , para. 2 , and art. 85 , para. 2 .

${ }^{33}$ Regulation $1 / 2003$, supra note 9 , at art. 20 , para. 4 , and art. 21, paras. 1-2; SSM Regulation, supra note 14 , at art. 12 , para. 3; and SSM Framework Regulation, supra note 14, at arts. 129, 143; Regulation CRA, supra note 20, at art. 23d, para. 4; Regulation Emir, supra note 20, at art. 63, para. 4. The aviation sector is an exception: According to Regulation 2018/ 1139 , supra note 25 , at art. 76, para. 2, a decision is adopted in order to use the inspecting powers under Regulation 2018/1139, supra note 25, at art. 83, para. 2, and art. 85, para. 2. However, the consequences of the lack of cooperation of the inspected entity in an inspection order by a decision are not clarified.

${ }^{34}$ Regulation 1/2003, supra note 9, at art. 20, para. 6; SSM Regulation, supra note 14, at art. 12, para. 5; Regulation CRA, supra note 20, at art. 23d, para. 7; Reg. Emir, supra note 20, at art. 63, para. 7.

${ }^{35}$ See supra Section A.

${ }^{36}$ See sources cited supra note 14.

${ }^{37}$ See Regulation $2018 / 1139$, supra note 25 , at art. 84 , para. 1 .

${ }^{38}$ Regulation $1 / 2003$, supra note 9, at art. 20, paras. 3-4, and art. 21, para. 2; SSM Regulation, supra note 14, at art. 12, para. 1; Regulation CRA, supra note 20, at art. 23d, paras. 3, 4, 5, 7; Regulation Emir, supra note 20, at art. 63, paras. 3, 4, 5, 7.
} 
within an administrative procedure that is started and closed at the EU level. However, in the banking and the aviation sectors, a closer mechanism of integration takes place, as the inspection groups have a mixed composition, in which both EU officers and national ones take part. ${ }^{40}$

A more complex allocation of competences at the EU and national level takes place in the second group of cases, for example, the case of inspections of the European Anti-Fraud Office (OLAF), the European Fisheries Control Agency (EFCA), and the Directorate on Health and Food Audits and Analysis within the DG Health and Food Safety (Directorate-F).

OLAF - an internal office of the Commission, albeit enjoying autonomy and operational independence-was established in 1999, following the scandal that led to the resignation of the Santer Commission. ${ }^{41}$ OLAF's functions were originally governed by Regulation No. 1073/1999, later replaced by Regulation No. 883/2013, ${ }^{42}$ following numerous criticisms regarding the insufficiency of guarantees provided by OLAF for individuals. ${ }^{43}$ The subject of the administrative investigations of OLAF is confined to fraud and administrative irregularities which damage the financial interests of the EU. The newly established European Public Prosecutor Office (EPPO) has not absorbed OLAF's competences, as the first one is exclusively competent for criminal offenses and not administrative irregularities; ${ }^{44}$ yet, the need for coordination, according to the principles of cooperation and non-duplication of the investigation established in EPPO regulation is strong. Together with the aim of enhancing the effectiveness of OLAF's investigations, the purpose of facilitating coordination with EPPO is the primary reason for which Regulation No. 883/2013 has been recently reformed. ${ }^{45}$ OLAF inspections are divided into two types: Internal, in cases in which the activities under investigation are carried out by employees of European institutions,

\footnotetext{
${ }^{39}$ Regulation 1/2003, supra note 9, at art. 20, para. 5; SSM Regulation, supra note 14, at art. 12, paras. 4-5; Regulation CRA, supra note 20, at art. 23d, paras. 3, 4, 5, 7; Regulation Emir, supra note 20, at art. 63, para. 3, 4, 5, 7. For a comment on the obligation of cooperation between national authorities in the competition area, see ALISON JONES \& BRENDA SUFRIN, EU COMPETITION LAW 912 (6th ed. 2016).

${ }^{40}$ For the composition of inspection groups in the banking sectors, see SSM Framework Regulation, supra note 14, at art. 144. For the pool of inspectors in the aviation area, see Regulation 2018/1139, supra note 25, at art. 63.

${ }^{41}$ Commission Decision 1999/352 of 28 April 1999 Establishing the European Anti-fraud Office (OLAF), 1999 O.J. (L 136) 20. On the establishment of OLAF and its powers, see George Kratsas, A Case for OLAF: The Place and Role of the Anti-fraud Office in the European Union Context, 18 EUR. PUB. L. 65 (2012); Jan F.H. Inghelram, Judicial Review of Investigative Acts of the European Anti-Fraud Office (OLAF): A Search for a Balance, 49 Common MKT. L. REv. 601 (2012).

${ }^{42}$ Regulation 883/2013, of the European Parliament and of the Council of 11 Sept. 2013 Concerning the Investigations Carried out by OLAF and Repealing Reg. 1073/1999 and Reg. 1074/1999, 2013 O.J. (L 248) 1.

${ }^{43}$ Xavier Groussot \& Ziva Popov, What's Wrong With OLAF? Accountability, Due Process and Criminal Justice in European Anti-Fraud Policy, 47 Common MKT. L. Rev. 605, 635 (2010).

${ }^{44}$ Directive 2017/1371, of the European Parliament and of the Council of 5 July 2017 on the Fight Against Fraud to the Union's Financial Interests by Means of Criminal Law, 2017 O.J. (L 198) 29; Council Regulation 2017/1939 of 12 Oct. 2017 Implementing Enhanced Cooperation on the Establishment of the European Public Prosecutor's Office ('the EPPO'), 2017 O.J. (L 283) 1.

${ }^{45}$ Regulation (EU, Euratom) 2020/2223, of the European Parliament and of the Council of 23 Dec. 2020 Amending Regulation (EU, Euratom) No 883/2013, as Regards Cooperation with the European Public Prosecutor's Office and the Effectiveness of the European Anti-Fraud Office Investigations, 2020 O.J. (L 437) 49.

On the reasons leading to the reform of OLAF Regulation, see Commission Proposal for a Regulation of the European Parliament and the Council Amending Regulation (EU, Euratom) 833/2013 Concerning Investigations Conducted by the European Anti-Fraud Office (OLAF) as Regards Cooperation with the European Public Prosecutor's Office and the Effectiveness of OLAF Investigations, at 1-3, COM (2018) 338 final (June 23, 2018) (clarifying the need to adapt the ways of operating of OLAF to the establishment of EPPO and the aim of fostering the effectiveness of the Offices' investigations). On the limits of such investigations, see European Court of Auditors, Opinion No. 8/2018 on the Commission's Proposal of 23 May 2018 on Amending OLAF Regulation 883/2013 as Regards Cooperation with the European Public Prosecutor's Office and the Effectiveness of OLAF Investigations, (2019/C 42/01), 2019 O.J. (C 42) 1, 4-5.

Efforts intended to reform Regulation 883/2013 date back to the beginning of the decade; however, at the time they were focused on reinforcing procedural guarantees. See Commission Proposal for a Regulation of the European Parliament and the Council Amending Regulation (EU, Euratom) 833/2013 Regarding the Establishment of a Controller of Procedural Guarantees, COM (2014) 340 final (June 11, 2014). One aspect of such proposal—the establishment of the Controller of Procedural Guarantees-has been inserted in the most recent reform. See infra Section C.
} 
and external, where they are related to the conduct of economic operators in the territory of Member States. ${ }^{46}$

While OLAF can investigate any case harming the financial interests of the EU, in the other two sectors, the inspecting powers given at the EU level are carefully circumscribed. In fisheries, there is a broad responsibility of national authorities to control and inspect fishing activity. Inspection powers of EFCA, ${ }^{47}$ the EU agency responsible for fisheries, can be activated only upon very specific circumstances when EU vessels in international waters are concerned. ${ }^{48}$ Also, in the area of food safety, the primary responsibility to control is on national authorities. The Commission's controls, performed by Directorate F, are aimed at controlling how the Member States perform such control. ${ }^{49}$ However, the Commission's food safety on the spot verifications can also include access on business premises ${ }^{50}$ so that such control, even though being indirect, can have in practice a direct effect on individuals, as the Bowland case shows. ${ }^{51}$

The type of powers that can be used by these EU inspectors are similar to those examined for the competition, banking, financial, and aviation areas. They include controls and spot checks, access to information and documentation, extracting copies of documents, and requesting oral explanations. ${ }^{52}$ The most intrusive powers given in the sectors examined above-to seal premises or gather telephone and data traffic-are not mentioned. However, OLAF is entrusted with two particularly intrusive powers. First, in addition to extracting copies of documents, the appointed officials may also, "if necessary," take possession of them "to avoid any risk of subtraction." 53 Second, according to the recently reformed OLAF Regulation, the Office shall have access to information also stored in privately owned devices, when used for work purposes, and to bank account information. ${ }^{54}$

The substantial and procedural conditions to activate the inspecting powers of EFCA and Directorate $\mathrm{F}$ are less specific than those that have been examined for the competition, banking,

In the following pages, Regulation $883 / 2013$ will be referred to as amended by Regulation 2020/2223, unless otherwise specified.

${ }^{46}$ Regulation $883 / 2013$, supra note 42 , at arts. 3-4.

${ }^{47}$ Its powers of inspection are governed by Council Regulation 1224/2009 of Nov. 20, 2009, Establishing a Community Control System for Ensuring Compliance with the Rules of the Common Fisheries Policy, Amending Regulations (EC) 847/96, (EC) 2371/2002, (EC) 811/2004, (EC) 768/2005, (EC) 2115/2005, (EC) 2166/2005, (EC) 388/2006, (EC) 509/2007, (EC) 676/2007, (EC) 1098/2007, (EC) 1300/2008, (EC) 1342/2008, and Repealing Regulations (EEC) 2847/93, (EC) 1627/ 94 and (EC) 1966/2006, 2009 O.J. (L 343) 1.

${ }^{48}$ Regulation 2019/473 of the European Parliament and of the Council of Mar. 19, 2019, on the European Fisheries Control Agency, art. 3, para. 1(i), and art. 19, 2019 O.J. (L 83) 18; Regulation 1224/2009, supra note 47, at art. 79. For a comment, see Federica Cacciatore \& Mariolina Eliantonio, Fishing in Troubled Waters? Shared Enforcement of the Common Fisheries Policy and Accountability Gaps, in LAW ENFORCEMENT BY EU AUTHORITIES, supra note 1, 170-74.

${ }^{49}$ Regulation 2017/625, of the European Parliament and of the Council of 15 March 2017 on Official Controls and Other Official Activities Performed to Ensure the Application of Food and Feed Law, Rules on Animal Health and Welfare, Plant Health and Plant Protection Products, Amending Regulations 999/2001, 396/2005, 1069/2009, 1107/2009, 1151/2012, 652/ 2014, 2016/429 and 2016/2031 of the European Parliament and of the Council, Council Regulations 1/2005 and 1099/2009 and Council Directives 98/58/EC, 1999/74/EC, 2007/43/EC, 2008/119/EC and 2008/120/EC, and Repealing Regulations 854/ 2004 and 882/2004 of the European Parliament and of the Council, Council Directives 89/608/EEC, 89/662/EEC, 90/425/EEC, 91/496/EEC, 96/23/EC, 96/93/EC and 97/78/EC and Council Decision 92/438/EEC (Official Controls Regulation), arts. 14, 116-18, 2017 O.J. (L 95) 1. For a general overview on the EU system of control in food safety, see DARIO BEVILACQUA, LA SICUREZZA ALIMENTARE NEGLI ORDINAMENTI GIURIDICI ULTRASTATALI (Giuffré ed., 2012).

${ }^{50}$ Regulation 2017/625, supra note 49, at art. 119.

${ }^{51}$ Case T-212/06, Bowland Dairy Products v. Comm'n, 2009 E.C.R. II-04073. See also Antonia Corini, Bernd van der Meulen, Floris Kets, Giuseppa Ottimofiore, Florentin Blanc, Enforcement of EU Food Law, in LAW ENFORCEMENT BY EU Authorities, supra note 1, at 204. See infra Section E.

${ }^{52}$ For OLAF, see Regulation 883/2013, supra note 42, at art. 3, paras. 2-3, and art. 4, para. 2; for Directorate F, see Reg. 2017/ 625, supra note 4949, at art. 119; for EFCA, see Regulation 1224/2009, supra note 47, at art. 79, para. 1, no. 4. In this latter case, request for oral information is not explicitly mentioned.

${ }^{53}$ Regulation $883 / 2013$, supra note 42 , at art. 4 , para. 2 .

${ }^{54} I d$. at art. 3, para. 5, and art. 4, para. 2. 
and financial areas. OLAF is an exception. A substantial condition for the initiation of an investigation is that there is sufficient suspicion to lead to the supposition of the existence of fraud, corruption, or other activity detrimental to the financial interests of the EU. From a procedural point of view, a decision of the Director-General is necessary in order to open an investigation. ${ }^{55}$ The powers to be used during the inspections, however, are specified in a written authorization of the Director-General, not in a decision. ${ }^{56}$ The economic operator has a duty to cooperate; however, if the economic operator resists the inspection, law enforcement authorities of the Member States shall provide assistance through the use of force.$^{57}$ Contrary to the competition, banking, and financial sectors, no pecuniary sanctions are specified in case of opposition.

As opposed to the first group of cases, in the area of the protection of financial interests, fisheries, and food safety, the competence for inspecting is separated from the one for sanctioning. At the end of the investigation, OLAF prepares a report describing the preliminary findings and recommendations. Those recommendations shall indicate disciplinary, administrative, financial, or judicial action to be taken by the institutions, bodies, offices, and agencies of the EU and by the competent authorities of the Member States concerned. Such recommendations have no binding legal effect on the EU or Member States authorities. ${ }^{58}$ It is up to the EU institution or national authorities to decide whether to proceed in taking administrative or judicial action. In the area of fisheries, EFCA does not sanction violations: It is in the competence of Member States to undertake all appropriate measures in respect of any infringement that a Community inspector has discovered. ${ }^{59}$ Similarly, in the area of food safety, at the end of its inspections, Directorate F produces reports that can be followed by actions by Member States. ${ }^{60}$

After examining the increasing phenomenon of EU authorities' inspection powers, this Article will now examine the conditions under which these powers are lawful, according to the common principles stemming from the national constitutions of the Member States, the EUCFR, and the ECHR.

\section{Inspection Powers, Fundamental Rights, and Judicial Review}

As inspections are visits and checks conducted on business premises and documents, they always have an impact on the inviolability of the home. As documents are increasingly dematerialized and can be found in hard disks, emails, and the like, checks during inspections can have a bearing on the right to the inviolability of communications. One specific power examined above, ESMA's power to gather telephone and data traffic, always affects the right to the inviolability of communications. What are the conditions for the public intervention intrusion on fundamental rights to be lawful?

The fundamental right to the inviolability of the home and communications is protected by the national constitutions of the Member States, the EUCFR, and the ECHR. A discussion of the evolution of the protection of fundamental rights in the EU, well known and extensively debated in the academic legal literature, ${ }^{61}$ falls beyond the scope of this Article. However, in order to set forth

\footnotetext{
${ }^{55} \mathrm{Id}$. at art. 5 , para. 1.

${ }^{56} I d$. at art. 3, para. 7, and art. 7, para. 2.

${ }^{57} I$. at art. 3, para. 4, and art. 4, para. 2.

${ }^{58}$ This lack of binding legal effect has long been clarified in the case law of the Court of Justice, discussed in this Article under Section E, and has been specifically recognized in Regulation 2020/2223, supra note 45, at art. 30.

${ }^{59}$ Regulation $1224 / 2009$, supra note 47 , at art. 87.

${ }^{60}$ Regulation 882/2004, of the European Parliament and of the Council of 29 April 2004 on Official Controls Performed to Ensure the Verification of Compliance with Feed and Food Law, Animal Health and Animal Welfare Rules, art. 45, paras. 2-3, 2004 O.J. (L 165) 1.

${ }^{61}$ For a general introduction, see, inter alia, THE EU AND HUMAN Rights (Philip Alston \& Joseph H. Weiler eds., 1999); Gráinne de Búrca, The Evolution of EU Human Rights Law, in The Evolution of EU LAw 465 (Paul Craig \& Gráinne de Búrca eds., 2011).
} 
the basis for assessing to which extent the different sources of protection of fundamental rights can limit the inspection powers of EU authorities, some rudimentary clarifications are needed.

Since the 70s, the Court of Justice started building an unwritten bill of rights, distilling general principles of law emerging from the common constitutional traditions of the Member States. ${ }^{62}$ Along with national traditions, in the construction of this unwritten bill of rights, the ECHR has also played a key role as a source of inspiration. ${ }^{63} \mathrm{~A}$ written bill of rights for the EU, the EU Charter of fundamental rights, was then drafted in 2000. When approved, however, it lacked binding legal force. Since the Treaty of Lisbon, the three possible sources of protection of fundamental rights under EU law have been codified under Article 6 TEU: The EUCFR, according to Article 6(1), has the same legal value as the Treaties; the ECHR, to which Article 6(2) provides a basis for accession and Article 6(3) recognizes a source of general principles of EU law; and national constitutional traditions of the Member States, which are also a source of general principles of EU law under Article 6(3).

Because the EU Charter was made formally binding, the CJEU tends to rely on the provisions of this source in the majority of the cases. In contrast, the frequency of citations of the ECHR and the reference to national constitutional traditions as a source of the common principles of EU law have declined. ${ }^{64}$ However, the TEU does not establish a hierarchy among the three sources of protection of fundamental rights. A pluralistic understanding of the relation between these sources appears preferable, as a comparative approach can help identify gaps in the protection offered by the EU Charter. ${ }^{65}$

Further clarification is needed, as far as the ECHR is concerned. On the one hand, it is well known that the Court of Justice, with its opinion 2/13, blocked the process of accession in the short term. ${ }^{66}$ On the other hand, however, it must be born in mind that, even though the Treaties do not clarify the relation between the EUCFR and the ECHR, Article 52, paragraph 3, of the EU Charter itself specifies that "Insofar as this Charter contains rights which correspond to rights guaranteed by the Convention for the Protection of Human Rights and Fundamental Freedoms, the meaning and scope of those rights shall be the same as those laid down by the said Convention." According to the Explanations to the Charter, the reference to the ECHR under Article 52, paragraph 3, covers not only the text of the Convention and the Protocols to it but also the meaning and the scope of the guaranteed rights as determined by the case law of the Strasbourg Court. ${ }^{67}$ Even if the legal value of these explanations is uncertain, ${ }^{68}$ in several cases, the CJEU has recognized that, when the provisions of the EU Charter correspond to those covered by the Convention, they shall have the same meaning and scope as interpreted by the Strasbourg Court. ${ }^{69}$ The approach of the Luxembourg Court, however, is far from settled, as in other cases the expression used is more

\footnotetext{
${ }^{62}$ Bruno de Witte, The Past and Future Role of the European Court of Justice in the Protection of Human Rights, in THE EU AND Human Rights, supra note 61, at 859.

${ }^{63}$ Case 4/73, J. Nold v. Comm'n, 1974 E.C.R. 491, para. 13.

${ }^{64}$ Gráinne de Búrca, After the EU Charter of Fundamental Rights: The Court of Justice as a Human Rights Adjudicator, 20 MAastricht J. Eur. \& COMP. L. 168, 174-75 (2013); Sionaidh Douglas-Scott, The Relationship Between the EU and the ECHR Five Years on from the Treaty Of Lisbon, in THE EU Charter of Fundamental Rights as a Binding Instrument: Five Years Old and Growing, 21 (Sybe De Vries, Ulf Bernitz \& Stephen Weatherill eds., 2015).

${ }^{65}$ Herwig C.H. Hofmann \& C. Mihaescu, The Relation Between the Charter's Fundamental Rights and the Unwritten General Principles of EU Law: Good Administration as the Test Case, 9 Eur. Const. L. Rev. 73, 77-82 (2013); Robert Schütze, Three 'Bills of Rights' for the European Union, 30 Y.B. EUR. L. 131 (2011).

${ }^{66}$ Case C-2/13, Opinion 2/13 of the Court, ECLI:EU:C:2014:2454, (Dec. 18, 2014), http://curia.europa.eu/juris/liste.jsf? num=C-2/13. On opinion 2/13 and its consequences, see, for example, Adam Łazowski \& Ramses R. Wessel, When Caveats Turn into Locks: Opinion 2/13 on Accession of the European Union to the ECHR, 16 GERMAN L.J. 179 (2015); Steve Peers, The EU's Accession to the ECHR: The Dream Becomes a Nightmare, 16 GERMAN L.J. 213 (2015).

${ }^{67}$ Explanations Relating to the Charter of Fundamental Rights, 2007 O.J. (C 303) 17.

${ }^{68}$ Koen Lenaerts, Exploring the Limits of the EU Charter of Fundamental Rights, 8 Eur. ConsT. L. REv. 375, 401-02 (2012).

${ }^{69}$ Case C-400/10, J. McB. v. L. E., 2010 E.C.R. I-08965, para. 53; Case C-205/15, Direcția Generală Regională a Finanțelor Publice Brașov (DGRFP) v. Vasile Toma, para. 41, (June 30, 2016), http://curia.europa.eu/juris/liste.jsf?num=C-205/15; Case
} 
generic, arguing that the ECHR case law needs "to be taken into consideration" in determining such meaning. ${ }^{70}$

In the following paragraphs, the different models of protection of the fundamental rights of the inviolability of the home and the secrecy of communications under national Constitutions, under the ECHR, and under the ECFR, will be examined, as they can constitute limits to the exercise of inspection powers of EU authorities. Only the use of a comparative methodology can help to understand the reasons behind different models of protection of fundamental rights and whether different models are equally effective in protecting such rights. Moreover, as will be seen, both the Court of Strasbourg and the Court of Luxembourg, albeit using different techniques of protection of fundamental rights, take into account conditions that are traditionally considered relevant under national constitutional traditions, notably through the proportionality test.

Under national constitutional law, the system of protection for the inviolability of the home and communications is generally based on two guarantees: First, that such power must be specified in a legislative act, and second, in some Member States, ex ante judicial authorization. ${ }^{71}$ However, while all EU Member States' national Constitutions require that any limitations shall have a legal basis, only some of them set forth that such limitation shall be authorized by a judge: For example, this is the case under French law, while the German and Italian Constitutions, albeit considering the principle, draw a distinction concerning the cases when such preventive judicial authorization is required.

Under French law, the Conseil Constitutionnel clearly stated that ex ante judicial authorization is necessary for public officials to enter private premises within administrative inspections. ${ }^{72}$ In Germany, there is a distinction between Durchsuchungrecht, in which the use of force requires a prior warrant, and Einsichts und Prüfungsrecht, in which the searches are conducted with the consent of the inspected and hence, prior authorization is not needed. ${ }^{73}$ Article 14 of the Italian Constitution exempts administrative inspections from judicial authorization when this is needed for the purpose of objectives of public interest, and the Constitutional Court interpreted such distinction in a similar way to the German tradition, distinguishing between perquisizioni (use of force and hence the necessity of preventive authorization) and ispezioni (consent and no preventive authorization).$^{74}$

The differences across national Constitutional traditions of the Member States on the requirement of ex ante judicial authorization for the inviolability of the home led the Court of Justice to find that such a requirement cannot be considered a general principle of EU law, as will be discussed in the following section.

After pointing out the differences existing within some national constitutions of the Member States, the analysis now turns to the ECHR and the EUCFR.

The inviolability of the home and the secrecy of communication are protected under Article 8 ECHR. In recognizing that "[e]veryone has the right to respect for his private and family life, his

C-419/14, WebMindLicenses Kft. v. Nemzeti Adó- és Vámhivatal Kiemelt Adó- és Vám Foigazgatóság, para. 70, (Dec. 17, 2015), http://curia.europa.eu/juris/liste.jsf?num=C-419/14.

${ }^{70}$ Case C-398/13 P, Inuit Tapiriit Kanatami v. Comm'n, para. 61, (Sept. 3, 2015) http://curia.europa.eu/juris/liste.jsf?num= C-398/13; Case C-601/15, J.N. v. Staatssecretaris voor Veiligheid en Justitie, para. 44, (Feb. 15, 2016), http://curia.europa.eu/ juris/liste.jsf?num=C-601/15.

${ }^{71}$ See Cananea, supra note 6, at 181.

${ }^{72}$ Conseil constitutionnel [CC] [Constituional Court], decision No. 83-164DC, Dec. 29, 1983, para. 28 (Fr.) (“Considérant cependant que, si les nécessités de l'action fiscale peuvent exiger que des agents du fisc soient autorisés à opérer des investigations dans des lieux privés, de telles investigations ne peuvent être conduites que dans le respect de l'article 66 de la Constitution qui confie à l'autorité judiciaire la sauvegarde de la liberté individuelle sous tous ses aspects, et notamment celui de l'inviolabilité du domicile; que l'intervention de l'autorité judiciaire doit être prévue pour conserver à celle-ci toute la responsabilité et tout le pouvoir de contrôle qui lui reviennent.") (emphasis added).

${ }^{73}$ Opinion of Advocate general Mischo at 49-111, Joined cases 97 \& 98 \& 99/87, Hoechst AG v. Comm'n (21 February 1989), https://eur-lex.europa.eu/legal-content/EN/TXT/?qid=1594971626993\&uri=CELEX:61987CC0046.

${ }^{74}$ Corte Cost., 2 February 1971, n. 10, para. 3 (It.); Corte Cost., 31 March 1987, n. 88, para 3 (It.). 
home and his correspondence," Article 8 ECHR embraces four different interests: Private life, family life, home, and correspondence. Article 8 ECHR requires that such interference must be "in accordance with the law" and that it must be "necessary in a democratic society" in order to pursue one of the public interests listed in the provision. ${ }^{75}$ The ECHR primarily imposes a duty not to interfere, hence a negative obligation. Positive obligations vary on the basis of a number of factors, such as the importance of the right and the resources a public authority would need to take positive actions. ${ }^{76}$ In its reasoning, the Court usually examines the elements of the accordance with the law, of the identification of the legitimate aim and the "necessity" of the interference in this order; if its finds that one of these requirements is not met, it is not necessary to review compliance with the other requirements. ${ }^{77}$ That the interference is "necessary in a democratic society" translates into a requirement of proportionality to the legitimate aim pursued, implying a "fair balance" between the right of the individual and various public interests. ${ }^{78}$

The wording of Article 7 of the EU Charter of Fundamental Rights corresponds perfectly to the first paragraph of Article 8 of the ECHR. ${ }^{79}$ Even though this Article does not specify the proportionality test, such a test does nevertheless apply for two reasons. First, because of the general correspondence clause under Article 52, paragraph 3, of the Charter, mentioned above, which, as clearly stated in the Explanations to the Charter, also applies to Article $7 .{ }^{80}$ Second, according to the first paragraph of Article 52:

Any limitation on the exercise of the rights and freedoms recognized by this Charter must be provided for by law and respect the essence of those rights and freedoms. Subject to the principle of proportionality, limitations may be made only if they are necessary and genuinely meet objectives of general interest recognized by the Union or the need to protect the rights and freedoms of others.

Therefore, proportionality is the guiding principle to assess any limitation to the right to privacy, not only because of the correspondence of Article 7 of the Charter to Article 8 of the ECHR, but also, as explicitly stated within the Charter itself - not only for privacy, but for all the rights listed in the Charter-and as a general principle of law.

The type of protection of the home and communication follows the same model in the ECHR and the EUCFR. It must be provided for in the law, and it is subject to the principle of proportionality. A significant difference, on the contrary, can be traced when comparing the type of protection that can be found in the national Constitutions, as neither the ECHR nor the EU Charter requires ex ante judicial authorization. However, the existence or the lack of such authorization can be, and has been, taken into account when assessing if a given limit to the right to privacy complies with the proportionality test, as will be seen in the following sections.

As preventive judicial control on inspections is taken into account when assessing the proportionality of public interference taking place during inspections, the rationale and function of such preventive control, as emerging from the case law of the Court of Strasbourg, need to be clarified.

\footnotetext{
${ }^{75}$ European Convention on Human Rights, art. 8, para. 2 (Nov. 4, 1950) [hereinafter ECHR] (“There shall be no interference by a public authority with the exercise of this right except such as is in accordance with the law and is necessary in a democratic society in the interests of national security, public safety or the economic well-being of the country, for the prevention of disorder or crime, for the protection of health or morals, or for the protection of the rights and freedoms of others.").

${ }^{76}$ See Harris, supra note 5 , at 504-05.

${ }^{77}$ See, e.g., Heino v. Finland, App. No. 56720/09, para. 49 (Feb. 15, 2011), http://hudoc.echr.coe.int/eng?i=001-103394.

${ }^{78}$ Dawn Oliver, Common Values and the Public-Private Divide, 232 (1999); Jonas Christoffersen, Fair Balance: Proportionality, Subsidiarity and Primarity in the European Convention on Human Rights 31 (2009).

${ }^{79} \mathrm{ECHR}$, art. 7 ("Everyone has the right to respect for his or her private and family life, home and communications.").

${ }^{80}$ Draft Charter Of Fundamental Rights Of The European Union 10 (2000), http://www.europarl.europa.eu/charter/pdf/ 04473_en.pdf (explaining and clarifying provisions of the Charter).
} 
First, the key rationale for the requirement of prior judicial authorization is that it limits the discretion of the executive. ${ }^{81}$ Second, ex ante control pursues the aim of preventing an unlawful intrusion in the private sphere to take place. ${ }^{82}$ Once such intrusion has taken place-for example, if personal documents have been copied-it is irreversible. ${ }^{83}$

The first purpose of preventive judicial authorization - the one of limiting discretion — can also be pursued through an authorization of the executive power. For instance, the decision of the Commission authorizing the inspectors has the purpose both of authorizing the inspectors and of circumscribing their power. ${ }^{84}$ However, the idea behind the requirement of a preventive judicial control is the one that controls on such discretion should stem from a neutral authority, ${ }^{85}$ an aim that cannot be guaranteed when the authorization, instead of a judicial one, is issued by an authority which is part of the EU executive.

An instrument other than the one of ex ante judicial authorization and equally capable of fulfilling the second objective-preventing an unlawful public intrusion to take place, because, for example, the inspection is based on a manifestly unlawful decision to inspect-is not easy to identify. However, obtaining a prior judicial warrant is time-consuming, and such time consumption can impair the effectiveness of the search. This makes it necessary to find instruments that, even if they cannot prevent a violation of the right of the inviolability of the home to take place, can ensure that, should an unlawful intrusion take place, an ex post full restoration can take place after the inspection. ${ }^{86}$

Moreover, in some cases, ex ante judicial authorization cannot be sufficient to prevent an unlawful public interference on the fundamental rights of the inspected party. Such preventive authorization, by definition, controls the content and conditions stated in the decision to inspect. It cannot prevent an unlawful interference when, for instance, the investigation activities of the inspectors go beyond the powers that are authorized in the decisions to inspect. For example, because the documents that are seized are not covered by the decision, or because the EU officers inspect the premises of a company different from the addressee of the inspection as identified in the decision to inspect. This can explain why in some cases, the Court of Strasbourg declared unlawful the intrusion that had taken place within an inspection that had been authorized ex ante by a national judge. ${ }^{87}$

The arguments explained above suggest: a) that limitations to ex ante judicial authorization should be attentively scrutinized; and $b$ ) that the features of a full ex post judicial review on inspections are crucial for the public interference to be lawful, even when ex ante judicial authorization is in place, as the latter can control only the decision to inspect, and not the subsequent activities.

The analysis will now turn to the case law of the Court of Luxembourg and the Court of Strasbourg, showing that they set forth different conditions that need to be met in order to compensate for the lack of ex ante judicial authorization.

\footnotetext{
${ }^{81}$ Heino, App. No. 56720/09 at para. 42; Delta Pekárny A.S. v. Czech Republic, App. No. 97/11, para. 86 (Oct. 2, 2014), http://hudoc.echr.coe.int/eng?i=001-147075.

${ }^{82}$ Société Canal Plus v. France, App. No. 29408/08, para. 36 (Dec. 21, 2010) http://hudoc.echr.coe.int/eng?i=001-102436; Ravon et autres v. France, App. No. 18497/03, para. 28 (May 21, 2008), http://hudoc.echr.coe.int/eng?i=001-85185.

${ }^{83}$ VALENTINI, supra note 4 , at 119.

${ }^{84}$ See supra Section B.

${ }^{85}$ For a discussion of the rationale behind preventive judicial warrant under Article 14 of the Italian Constitution, see Antonio Amorth, La Costituzione italiana: commento sistematico 59 (1948); Alessandro Pace, Problematica DELLE LIBERTÀ COSTITUZIONALI: LEZIONI 211 (1992).

${ }^{86}$ VAlentini, supra note 4, at 119. For this perspective, see also Société Canal Plus, App. No. 29408/08 at para. 36; Ravon, App. No. 18497/03 at para. 28.

${ }^{87}$ See Société Canal Plus, App. No. $29408 / 08$ at paras. 30-1; Ravon, App. No. 18497/03 at paras. 39-41.
} 


\section{The Limits to Ex Ante Judicial Control: Comparing the Views of the Court of Luxembourg and the Court of Strasbourg}

The problem of the ex ante judicial authorization of inspections by the Commission was first raised in the 80s. In the 1989 Hoechst case, ${ }^{88}$ the German firm refused to give access to the Commission inspectors, arguing that a warrant was needed. In the absence of case law on the matter from the ECHR, the Court of Justice argued that the inviolability of home did not apply to business premises ${ }^{89}$ However, the Court considered that should national laws require such authorization, national procedures should be followed. ${ }^{90}$ Yet, given the necessity to maintain the unity of EU law, the control of national courts could not extend to the necessity of the measure, as this could only be assessed by the Court of Justice. ${ }^{91}$

More than ten years later, in the Roquette case in $2002,{ }^{92}$ the Court of Justice changed its approach on this point. In doing so, it was influenced by the evolution of the case law of the ECHR after the Hoechst case. In the Niemetz and Colas Est cases, the ECHR recognized that the protection of the domicile, as per Article 8 of the ECHR, is also applicable to certain activities or business or commercial premises. ${ }^{93}$ However, in the Colas Est case, the Strasbourg Court also stated that the lack of ex ante prior judicial authorization was one of the elements to be taken into account in assessing whether such interference on the inviolability of the home was proportionate to the legitimate aim of public interest pursued with the investigation. ${ }^{94}$

In the Roquette case, the Court of Justice considered the inviolability of the home to be applicable to business premises. ${ }^{95}$ It confirmed that if national jurisdictions required prior judicial authorization, such procedures should be followed. However, the Court defined the object and scope of the power of the national court responsible for issuing the authorization to conduct the inspections. This power is not full: The assessment of the necessity of the investigations rests exclusively with the Court of Justice, ${ }^{96}$ while the control carried out by the national court cannot go beyond the verification of the absence of arbitrariness and the proportionality of the enforcement measures. ${ }^{97}$ In order to enable the national court to carry out that assessment, the Commission "is obliged to provide said court with explanations which make it clear that the Commission possesses elements and evidence in its file that justify the suspicion of infringements of competition rules by the undertaking in question." ${ }^{\prime 98}$ This, therefore, is a significant increase in the obligation of the Commission to state reasons and, consequently, of the effectiveness of the monitoring carried out by the national court. If it should consider that it does not have sufficient information, the national court may ask the Commission for "additional information," ${ }^{99}$ but they cannot request direct access to the file. ${ }^{100}$ Only in the event of insufficient information being provided, or in the absence of appropriate answers from the Commission, is the national court entitled to refuse authorization. ${ }^{101}$

\footnotetext{
${ }^{88}$ Joined Cases C-46 \& 227/88, Hoechst AG v. Comm'n, 1989 E.C.R. I-02859.

${ }^{89} \mathrm{Id}$. at para. 17.

${ }^{90} I d$. at para. 34 .

${ }^{91} I d$. at para. 35 .

${ }^{92}$ Roquette Frères, Case C-94/00.

${ }^{93}$ Niemetz v. Germany, App. No. 13710/88, para. 11 (Dec. 16, 1992), http://hudoc.echr.coe.int/eng?i=001-57887; Société Colas Est v. France, App. No. $37971 / 97$ (Apr. 16,2002), http://hudoc.echr.coe.int/eng?i=001-60431.

${ }^{94}$ Société Colas Est, App. No. 37971/97 at para. 49; see also Funke v. France, App. No. 10588/83 (Feb. 25, 1993), http://hudoc. echr.coe.int/tur?i=001-57809.

${ }^{95}$ Roquette Frères, Case C-94/00 at paras. 20, 29.

${ }^{96} I d$. at paras. 39,51 .

${ }^{97} I d$. at paras. $39-40$.

${ }^{98} \mathrm{Id}$. at para. 61.

${ }^{99} \mathrm{Id}$. at paras. $91-94$.

${ }^{100} I d$. at para. 62.

${ }^{101} I d$. at paras. $91-94$.
} 
The division of tasks between the national courts and the Court of Justice set forth in the Roquettes case was codified in the 2003 Regulation. ${ }^{102}$ The prior authorization of the national judge-which is always necessary for inspections of places of residence, particularly when the inspected entities formally oppose the inspection if national law requires such authorization ${ }^{103}$ - constitutes a first protection for the individual, against actions that are manifestly arbitrary or disproportionate. Through the broadening of the duty to give reasons for the Commission, the powers of national courts to control that the enforcement measures are not manifestly arbitrary or disproportionate have been extended compared to the Hoechst case, and, as a result, so have the guarantees for the individual. However, the powers of the national judges are still limited, as they cannot assess the necessity for investigations in relation to the aim being pursued, ${ }^{104}$ and they cannot access the file, ${ }^{105}$ while the full control on the lawfulness of the decision is reserved to the Court of Justice. The latter subsequently intervenes in a non-preventive way: The right to submit an appeal to the Court of Justice against the Commission's decisions to inspect is explicitly recognized. ${ }^{106}$

The model of judicial control that emerged in the area of competition as a result of the Court of Justice case law and codified in Reg. No. 1/2003 has been extended to other sectors. Against the inspections of the ESMA and the ECB, the system of judicial protection is identical to that of the competition sector: There is a need for prior judicial approval only if this is required by national legislation; there are the same limits to the powers of control of the national court, aimed at verifying the absence of arbitrariness and proportionality; and the full control on the necessity and lawfulness of the decision is reserved to the Court of Justice. ${ }^{107}$ Therefore, the limits of the judicial protection examined with regard to the competition sector also apply in this area, and recently emerged in the first case of inspections of the ESMA against a British trade repository (TR), one of the objects of ESMA direct supervision as analyzed above. ${ }^{108}$ In this case, in line with the national regulations, the judicial authorization had been requested in advance, although the TR in question did not oppose the inspection. ${ }^{109}$ Also, in the area of aviation safety, the preventive judicial authorization is necessary when national legislation requires so. ${ }^{110}$ However, in this sector, preventive authorization is necessary only to enter relevant premises, land, and means of transport, and not to execute the other inspecting powers, such as those to request documents or information, and the limits to the powers of the national judge are not explicitly codified.

As far as other sectors are concerned, EU regulations do not clearly codify when ex ante judicial authorization is needed and what are the limits of such control. For EFCA's, EU regulations provide for compliance with rules and practices of the Member States concerned. ${ }^{111}$ In its first

\footnotetext{
${ }^{102}$ Regulation $1 / 2003$, supra note 9 , at art. 20, para. 8 , and art. 21, para. 3 .

${ }^{103} I$ d. art. 21, para. 3, and art. 20, para. 7.

${ }^{104} I d$. art. 20, para. 8 , and art. 21 , para. 3 .

${ }^{105} \mathrm{Id}$. art. 20 , para. 8 , and art. 21 , para. 3 .

${ }^{106} I d$. art. 20, paras. $4-8$, and art. 21 , paras. $2-3$.

${ }^{107}$ SSM Regulation, supra note 14, at art. 13; Regulation CRA, supra note 20, at art. 23d, paras. 7-9; Regulation Emir, supra note 20 , at art. 63 , paras. 7-9.

${ }^{108}$ ESMA v. DTCC Derivatives Repository Ltd. [2015] EWHC 1085 (Ch) (Eng.). See supra Section B, footnote 21.

${ }^{109}$ Marloes van Rijsbergen \& Miroslava Scholten, ESMA Inspecting: The Implications for Judicial Control Under Shared Enforcement, 7 EUR. J. RISK REG. 569 (2016); Anastasia Sotiropoulou, L'ESMA et la sanction de Fitch: brèves réflexions sur les pouvoirs de surveillance de l'Autorité européenne des marchés financiers, BULLETIN JOLY BOURSE 423 (2016).

${ }^{110}$ Regulation $2018 / 1139$, supra note 25 , at art. 83, para. 2, and art. 85, paras. $2-5$.

${ }^{111}$ As for fisheries, see Commission Implementing Regulation 404/2011 of 8 April 2011, Laying Down Detailed Rules for the Implementation of Council Regulation 1224/2009, Establishing a Community Control System for Ensuring Compliance with the Rules of the Common Fisheries Policy, art. 122, para. 1, 2011 O.J. (L 112) 1 ("In the accomplishment of their tasks Union inspectors shall comply with the law of the European Union and, as far as applicable, the national law of the Member State where the inspection takes place or, where the inspection is carried out outside EU waters, of the flag Member State of the inspected fishing vessel and relevant international rules.").
} 
formulation, also OLAF Regulation referred to the Office's compliance with national rules in the context of external inspections. ${ }^{112}$

The requirement to comply with the national law of the Member State regarding EFCA's and OLAF's external inspections can be interpreted in the sense that a preventive judicial warrant should be asked when national law requires so. ${ }^{113}$ However, in the Sigma Orionis case, the General Court clarified that there is no obligation for OLAF inspectors to comply with national law, and in particular for a preventive warrant to be requested, unless the inspected entity formally resists the inspection. ${ }^{114}$ In this way, the Court added a condition for the application of national law - the one of the formal opposition of the inspected entity-that is inspired by the provisions applying to other sectors, such as the competition one, but that was not provided for under OLAF Regulation.

Finding that the limits of application of national law to the Office's investigative activity were not "completely clear" and with the purpose of taking into account the Sigma ruling, ${ }^{115}$ the recently approved reform of OLAF Regulation establishes that only Union law shall apply to OLAF's investigations. In contrast, national law, and in particular the prior warrant requirement, shall apply only when national officers assist OLAF and when an economic operator formally resists the inspection. ${ }^{116}$ The recent change to OLAF's Regulation further limits the scope of ex ante judicial authorization for OLAF's inspections and strengthens the argument according to which the lawfulness of inspection powers largely depends on the scope and features of ex post review.

Moreover, the recent reform of the OLAF Regulation provides for the establishment of a "controller of procedural guarantees," an administrative body with the task of monitoring the Office's compliance with procedural guarantees. ${ }^{117}$ However, while the first Commission proposal aimed at revising OLAF's Regulation assigned to the Controller, inter alia, the task of authorizing inspections, ${ }^{118}$ the approved text shapes the newly established Controller as an ex post mechanism to review complaints alleging infringements of procedural rules or fundamental rights. ${ }^{119}$ The establishment of the Controller is significant for two reasons. First, it further reinforces a model of control in which guarantees operate ex post and not preventively, in order to avoid any type of potential obstacle to the investigation activity, as strengthening the efficiency of OLAF is one of the main objectives of the reform. Second, the establishment of the Controller as an administrative complaint mechanism, which is not an alternative to judicial remedies and that can issue recommendations that are not-binding on OLAF's Director-General, ${ }^{120}$ adds a new non-judicial remedy that economic operators can use to protect their rights. The Controller works as a sectorspecific complaint instrument that could be activated in addition to any other means of redress available under EU law, ${ }^{121}$ including the general non-judicial remedy of the EU, for instance, the

\footnotetext{
${ }^{112}$ Before the amendments introduced with Regulation 2020/2223, as noted above in Section B, Regulation 883/2013, supra note 42 , at art. 3, para. 3 provided that, during on-the-spot checks and inspections in the context of external investigations, "the staff of the Office shall act, subject to the Union law applicable, in compliance with the rules and practices of the Member State concerned and with the procedural guarantees provided for in this Regulation" (emphasis added).

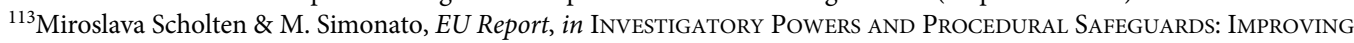
OLAF's LEgISLATIVE FrAmEWORK 9, 27 (Michiel Luchtman \& John Vervaele eds., 2017). For this line of reasoning about the aviation sector before the most reform of the Regulation, see Coman-Kund, supra note 24, at 123.

${ }^{114}$ Case T-48/16, Sigma Orionis SA v. Comm'n, paras. 80-81 (May, 3 2018), http://curia.europa.eu/juris/liste.jsf?num=T$48 / 16$.

${ }^{115} \mathrm{COM}$ (2018) 338 final, supra note 45, at 10; Regulation 2020/2223, supra note 45, at recitals 19-22.

${ }^{116}$ Regulation $833 / 2013$, supra note 42 , at art. 3, paras. $3-7$.

${ }^{117} \mathrm{Id}$. at art. $9 \mathrm{a}$.

${ }^{118}$ COM (2014) 340 final, supra note 45. See also European Court of Auditors, Opinion No. 6/2014 Concerning a Proposal for a Regulation of the European Parliament and of the Council Amending Regulation (EU, Euratom) No. 883/2013 as Regards the Establishment of a Controller of Procedural Guarantees, 2014 O.J. (C 419) 1, 4.

${ }^{119}$ Regulation $833 / 2013$, supra note 42 , at arts. 9a-9b.

${ }^{120} I d$. at art. $9 \mathrm{~b}$, para. $5-7$.

${ }^{121} I d$. at art. 9b, para. 8 .
} 
European Ombudsman, to whom any citizen of the EU can complain about maladministration. ${ }^{122}$ Moreover, the Controller can be considered part of a general tendency in the multiplication of sector-specific administrative review bodies. ${ }^{123}$ Even though administrative non-judicial instruments multiply the venues through which EU authorities can be called to give account of how they use their inspection powers, a full examination of these tools falls beyond the scope of this Article, which deals with the functioning of the principle of effective judicial protection.

What are the features of ex post judicial review on inspections so that the absence of prior authorization can be compensated? According to the case law of the ECHR and the Court of Justice, the weaknesses from the point of view of prior judicial protection can be counterbalanced for in the event of a full ex post judicial review which regards compliance with certain procedural requirements during inspections. However, the standards to assess such compensation appear stricter in the ECHR case law than in the Court of Justice. ${ }^{124}$

In the Deutsche Bahn case, the Court of Justice maintained that "the absence of prior judicial authorization may be counterbalanced by a post-inspection review covering both questions of fact and questions of law." ${ }^{25}$ In particular, the Court confirmed the argument that a lack of prior warrant is "only one of the factors borne in mind by the ECtHR when deciding whether Article 8 of the ECHR has been infringed," 126 and the lawfulness of inspections does not depend on prior judicial authorization. Instead, it relies on five categories of safeguards provided for by European law, ${ }^{127}$ namely:

[F]irst, the statement of reasons on which inspection decisions are based, second, the limits imposed on the Commission during the conduct of inspections, third, the impossibility for the Commission to carry out an inspection by force, fourth, the intervention of national authorities and, fifth, the existence of ex post facto remedies. ${ }^{128}$

The thesis, according to which the lack of prior judicial authorization might be counterbalanced through a full ex post judicial review can also be found also in the ECHR case law. Both in Heino and Delta Pekarny, the Court admitted the possibility of such compensation; yet, it argued that, when a preventive judicial authorization is lacking, the Strasbourg Court needs to be "particularly vigilant" 129 or "double" its control on whether the interference has been proportionate. ${ }^{130}$ In both cases, such double control resulted in the Court of Strasbourg stating that the existing safeguards were not sufficient to counterbalance the lack of a prior warrant and that an unlawful interference under Article 8 ECHR had occurred. ${ }^{131}$

\footnotetext{
${ }^{122}$ For a general overview on the European Ombudsman, see AcCOUNTABILITY IN THE EU: THE Role OF THE EUROPEAN Ombudsman (Herwig C.H. Hofmann \& Jacques Ziller eds., 2017).

${ }^{123}$ Luca De Lucia \& Paola Chirulli, Specialized Adjudication in EU Administrative Law: The Boards of Appeal of EU Agencies, 40 Eur. L. Rev. 832 (2015); Administrative Remedies in the European Union: The Emergence of a QUasi-Judicial Administration (Barbara Marchetti ed., 2017).

${ }^{124}$ Wouter P.J. Wils, EU Antitrust Enforcement Powers and Procedural Rights and Guarantees: The Interplay Between EU Law, National Law, the Charter of Fundamental Rights of the EU and the European Convention on Human Rights, 34 WORLD COMPETITION 41 (2011).

${ }^{125}$ Deutsche Bahn, Joined Cases T-289, T-290 \& T-521/11; Deutsche Bahn, Case C-583/13 P at para. 26.

${ }^{126}$ Deutsche Bahn, Joined Cases T-289, T-290 \& T-521/11 at para. 72.

${ }^{127}$ Deutsche Bahn, Case C-583/13 P at para. 28.

${ }^{128}$ Deutsche Bahn, Joined Cases T-289 \& 290 \& 521/11 at para. 74.

${ }^{129}$ Heino, App. No. 56720/09 at para. 40 ("Notwithstanding the margin of appreciation which the Court recognizes the Contracting States have in this sphere, it must be particularly vigilant where, as in the present case, the authorities are empowered under national law to order and effect searches without a judicial warrant.") (emphasis added).

${ }^{130}$ Delta Pekárny, App. No. 97/11 at para. 83 ("Lorsque le droit national habilite les autorités à conduire une perquisition sans mandat judiciaire, la Cour doit redoubler de vigilance, et ce nonobstant la marge d'appréciation qu'elle reconnaît en la matière aux États contractants. Ainsi, dans les affaires concernant la protection des individus contre des atteintes arbitraires de la puissance publique aux droits garantis par l'article 8, elle a eu l'occasion d'affirmer que l'absence d'un mandat de perquisition peut être compensé par un contrôle judiciaire effectif, réalisé ex post facto.”) (emphasis added).

${ }^{131}$ Heino, App. No. 56720/09 at para. 45; Delta Pekárny, App. No. 97/11 at para. 94.
} 
The Strasbourg Court clarified that, in order for ex post judicial review on inspections to be full and effective, four requirements must be met. ${ }^{132}$ First, the review must be both on questions of law and aspects of fact. Second, not only the decision ordering the investigation but also the activity following such decision must be subjected to judicial control. Third, ex post judicial review must be certain. Fourth, it must be within a reasonable time limit. While in Delta Pekarny the conditions for an effective ex post judicial control on inspections were examined in order to assess whether inspections complied with Article 8 ECHR, in Canal Plus and Ravon, the compatibility with Article 6 ECHR, concerning the right to a fair trial, was taken into account. However, the same conclusions as the features for a full ex post judicial review on inspections were reached.

According to the Court of Strasbourg, the features of ex post judicial control are crucial in compensating for the lack of a prior judicial warrant. Whether the type of ex post judicial remedies for inspections of EU authorities complies with the criteria that the Court of Strasbourg considers essential for such scrutiny to be full and effective is doubtful, as the next section will show.

\section{E. The Ex Post Judicial Control on Inspections: The Dual Model and its Shortcomings}

In order to assess whether the ex post judicial control on inspections of EU authorities is full, according to the criteria of the Court of Strasbourg, inspection powers need to be distinguished, as suggested at the beginning of this analysis, into two groups. In some sectors such as competition, banking, financial, aviation, it is expressly provided that the decision to inspect can be challenged before the Court of Justice. ${ }^{133}$ This happens in the areas in which the same EU administration that conducted the inspection also has the power to adopt the sanctions. ${ }^{134}$ In other areas, such as OLAF's, EFCA's, and Directorate F's inspections, where the check conducted during the investigation can be used for administrative or penal sanctions, adopted by a separate body-whether it is an EU or a national one- the inspecting decision cannot be autonomously challenged. In this second group of cases, the lawfulness of the inspecting decision can only be challenged together with the final act. This is why there is no single system of ex post judicial control on inspections of EU authorities, but a dual one. The shortcomings in each one of the two cases are different.

The main remedy applicable in the first group of cases-based on the right of the inspected entities to plea for the annulment of the decision to inspect before the Court of Justice-emerged in the competition area, and has been extended to the banking and the financial sectors. So far, the majority of the cases concern the competition area. In three recent cases, a number of French undertakings and associations of undertakings in the food and non-food distribution sector contested some decisions to inspect alleging, inter alia, the infringement of the right to an effective remedy, guaranteed under Article 47 EUCFR and corresponding to Article 6 ECHR. ${ }^{135}$

\footnotetext{
${ }^{132}$ Société Canal Plus, App. No. 29408/08 at paras. 36-45; Ravon, App. No. 18497/03 at para. 28; Delta Pekárny, App. No. 97/11 at paras. $90-92$.

${ }^{133}$ Regulation $1 / 2003$, supra note 9, at art. 20, para. 8 and 21, para. 3; SSM Regulation, supra note 14, at art. 13, para. 2; Regulation CRA, supra note 20, at art. 23d, para. 9; Regulation Emir, supra note 20, at art. 63, para. 9; Regulation (EC) No 216/ 2008 OF the European Parliament and of the Council of 20 February 2008 on Common Rules in the Field of Civil Aviation and Establishing a European Aviation Safety Agency, and Repealing Council Directive 91/670/EEC, Regulation (EC) No 1592/ 2002 and Directive 2004/36/EC, art. 44, 2008 O.J. (L 79) 1.

${ }^{134}$ This is slightly different in the aviation sector since it is the Commission, not EASA, that adopts the sanction. See Regulation 2018/1139, supra note 25, at art. 84, para. 1.

${ }^{135}$ See Case T-249/17, Casino, Guichard-Perrachone \& AMC v. Comm'n (Oct. 5, 2020), http://curia.europa.eu/juris/liste.jsf? num=T-249/17; Case T-254/17, Intermarché Casino Achats v. Comm'n (Oct. 5, 2020), http://curia.europa.eu/juris/liste.jsf? num=T-254/17; Case T-255/17, Les Mousquetaires \& ITM Entreprises v. Comm'n (Oct. 5, 2020), http://curia.europa.eu/juris/ liste.jsf?num=T-255/17. At the time of writing, the Casino, Guichard-Perrachone \& AMC v. Comm'n, formerly known as Casino, Guichard-Perrachone \& EMC Distribution v. Comm'n, judgment is available in some, but not all, the official languages of the EU. For purposes of this Article, as the English version is still not available, the French version has been referred to. For the other two cases, only some excerpts are currently available. For Les Mousquetaires \& ITM Entreprises, as the English version is still not available, the Italian version has been referred to.
} 
The General Court, acknowledging the need to take into account the case law of ECHR according to Article 52, paragraph 2, EUCFR and the Explanations to the Charter, ${ }^{136}$ and in particular, the principles stated by the Court of Strasbourg in the cases Canal Plus, Ravòn, and Delta Pekarny, recognized that the right to a full and effective judicial review of inspections requires four conditions to be satisfied. The conditions require that such review, both of the facts and points of law, covers the decision ordering the investigation and the "concerned measures"-the requirement of effectiveness; the existence of a remedy that can either prevent an infringement, or, where an unlawful act has taken place, can provide for an appropriate reparation-the requirement of efficiency; the certainty of access to proceedings - the requirement of certainty; that judicial review takes place within a reasonable time-the requirement of a reasonable time. ${ }^{137}$

For both the requirements of effectiveness and reasonable time, the possibility to challenge, together with the decision to inspect, also the acts performed during the inspection, is crucial. In Canal Plus, Ravòn, and Delta Pekarny, the Strasbourg Court argued, on the one hand, that not only the decision ordering the investigation but also the activity following such a decision must be subjected to judicial control. On the other hand, the possibility to challenge the inspecting acts only when the sanctioning decision is taken does not fulfill the requirement of providing a judicial review within a reasonable time limit. ${ }^{138}$ In arguing that the current system of remedies available under EU law in the competition sector fulfills these requirements, the General Court provided an innovative interpretation of its own case law, resulting in a partial extension of the instruments of review on inspections.

In Nexans, the General Court had considered that an action for the annulment of the acts performed during an inspection brought in the context of an action for the annulment of the decision to inspect was inadmissible and that the legality of such acts could be reviewed only in the context of an action challenging the final sanctioning decision. ${ }^{139}$ The only exception to this rule, first identified in the Akzo Nobel case and recalled in Nexans in order to argue that the case before the Court was different, was considered to emerge if the Commission requested to inspect documents covered by legal professional privilege. ${ }^{140}$ In Casino and Les Mousquetaires, the GC builds on this case law, arguing that, even though the inspecting acts should generally be reviewed together with the final sanctioning decision, an action against an inspecting act brought together with an action for the annulment of the inspection decision is admissible if two conditions are met. First, according to the $I B M$ case law, the inspecting act must "measure the legal effects of which are binding on, and capable of affecting the interests of," the applicant, "bringing about a distinct change in his legal position." 141 Second, such acts must constitute the final act of a special procedure distinct from the one that is intended to permit the Commission to take a decision on the substance of the case. ${ }^{142}$ In order for such a special procedure to be opened, the inspected entity must oppose the inspecting act before it takes place, raising the fact that such an act would directly affect the right to privacy of the party. In this way, the Commission is solicited to take a position, and its response, even a tacit one, through an omission, can amount to a reviewable act. ${ }^{143}$

Even though in Casino and Les Mousquetaires, the GC recognized in principle the possibility to anticipate ex post judicial review on inspecting acts-admitting that such acts can be challenged together with the inspection decision, and not with the final sanctioning act- hence potentially

\footnotetext{
${ }^{136}$ See supra Section C.

${ }^{137}$ Casino, Case T-249/17 at para. 50.

${ }^{138}$ Société Canal Plus, App. No. 29408/08 at paras. 36-45; Ravon, App. No. 18497/03 at para. 28; Delta Pekárny, App. No. 97/11 at paras. 90-2.

${ }^{139}$ Case T-135/09, Nexans France SAS \& Nexans SA v. Comm'n, para. 115-33 (Nov. 14, 2012), http://curia.europa.eu/juris/ liste.jsf?num $=\mathrm{T}-135 / 09$.

${ }^{140}$ Joined Cases T-125 \& 253/03, Akzo Nobel Chem. \& Akcros Chem. v. Comm'n, 2007 E.C.R. II-3523; Nexans, Case T-135/ 09 at paras. $127-28$.

${ }^{141}$ Case 60/81, Int'l Bus. Mach. Corp. v. Comm'n, 1981 E.C.R. I-02639, para. 9. See Casino, Case T-249/17 at para. 63; Les Mousquetaires, Case T-255/17 at para. 35 .

${ }^{142}$ Les Mousquetaires, Case T-255/17 at para. 35.

${ }^{143}$ Casino, Case T-249/17 at para. 62; Les Mousquetaires, Case T-255/17 at paras. 37-47.
} 
making judicial review on such acts more effective and taking place within a shorter-and hence more reasonable-time, the conditions set forth for this action to be admissible are extremely restrictive. In particular, the procedural conditions-for example, that the inspected party needs to formally object during the inspection, identifying specifically which documents can infringe its interest, such as was the case in Les Mousquetaires, where specific documents and mails could affect the private life of their employees ${ }^{144}$ _are hard to meet, especially when unannounced inspections take place. However, even with these limitations, the position expressed in Casino and Les Mousquetaires set forth the basis for an extension of the instruments of review on inspecting acts.

As for the requirement of efficiency of judicial review, such as the existence of a remedy that can either prevent an infringement, or, where an unlawful act has taken place, can provide for an appropriate reparation, the GC has developed two lines of reasoning. As for the prevention of an infringement, in Casino, the GC argued that an interim relief under Article 278 TFEU can be activated in order to ask for the suspension of an inspecting act. ${ }^{145}$ However, as the GC itself admitted, because the decision to inspect is normally notified the day the inspection is deemed to start in the competition section, a suspension can be obtained in very rare circumstances. ${ }^{146}$ As for the restoration, the GC argued that the action for damages, together with the impossibility for the Commission to rely on the results of an inspection conducted on the basis of a decision declared unlawful in order to impose a sanction, fulfilled such requirement. ${ }^{147}$ It was not considered that the inadmissibility of the request of the party to obtain the restitution of the documents infringing on the right to privacy of the employees ${ }^{148}$ could be in contrast with the requirement to provide for a full reparation.

For the second group of cases, there is no provision that explicitly entitles the inspected entities to challenge the decision to inspect. To understand the features of judicial protection of the individual subject to inspection in the sectors of the protection of EU financial interests, as well as fisheries and food safety, it is useful to concentrate the analysis on the first one, because the Court of Justice tends to extend such principles to other areas.

As mentioned above, at the end of OLAF's investigations, the director draws up a report, which describes the preliminary findings, provides a preliminary legal qualification and the estimated financial impact of the facts as established. This report is accompanied by disciplinary, financial, administrative, or judicial recommendations that are sent to the EU institution or competent authorities of the Member State concerned. ${ }^{149}$ Reports shall constitute admissible evidence in administrative or judicial proceedings, of criminal or non-criminal nature, before national courts or before the CJEU, according to the type of irregularity or fraud that was identified. ${ }^{150}$

The configuration of the recommendation of OLAF as non-binding has significant consequences from the point of view of subsequent judicial protection. Applying the IBM requirements, the Court has considered as non-reviewable under Article 263 TFEU, ${ }^{151}$ the decision to inspect, ${ }^{152}$ any inspecting acts, ${ }^{153}$ the inspection report and recommendations, ${ }^{154}$ and the transmission of

\footnotetext{
${ }^{144}$ Les Mousquetaires, Case T-255/17 at para. 47.

${ }^{145}$ Casino, Case T-249/17 at para. 64 .

${ }^{146} I d$.

${ }^{147} I d$. at paras. $74-76$.

${ }^{148}$ Les Mousquetaires, Case T-255/17 at para. 47.

${ }^{149}$ Regulation $883 / 2013$, supra note 42 , at art. 11 , para. 1 .

${ }^{150} I d$. at art. 11, para. 2.

${ }^{151}$ Case T-193/04, Hans-Martin Tillack v. Comm'n, 2006 E.C.R. II-03995, paras. 67-68, 70, 72.

${ }^{152}$ Case T-215/02, Santiago Gómez-Reino v. Comm'n, 2003 E.C.R. 2006 E.C.R. IA 345, para. 50; Case C-471/02 P(R), Santiago Gómez-Reino v. Comm'n, 2003 E.C.R. I-03207, para. 658; Case T-392/17, TE v. Comm'n, (July 12, 2018), http://curia.europa.eu/juris/liste.jsf?num=T-392/17.

${ }^{153}$ Santiago Gómez-Reino, Case T-215/02 at para. 50.

${ }^{154}$ Case T-29/03, Comunidad Autónoma de Andalucía v. Comm’n, 2004 E.C.R. II-02923, para. 40; Case T-309/03, Manel Camós Grau v. Comm'n, 2006 E.C.R. II-01173, paras. 55-58; Case T-4/05, Guido Strack v. Comm'n, 2006 FP-I-A-2-00083; Case C-237/06 P, Guido Strack v. Comm'n, 2007 E.C.R. I-00033; Case T-289/16, Inox Mare Srl v. Comm'n, para. 28 (June 21, 2017), http://curia.europa.eu/juris/liste.jsf?num $=\mathrm{T}-289 / 16$.
} 
information during the investigation. ${ }^{155}$ According to the Court, not only the report but also the recommendations lack legally binding effects, which could be detrimental to the individual sphere, as the authorities receiving such recommendation retain discretionary power on whether to follow such recommendations. ${ }^{156}$

Only in one case has the inspecting report been considered as a reviewable act; yet, the position taken by the Civil Service Tribunal in the Violetti case-and based on the specificity of the position of an EU officer object of an internal investigation ${ }^{157}$ - was reversed by the Court. ${ }^{158}$

According to the Court, the lack of admissibility of the action for the annulment against OLAF's inspections does not infringe the right to effective judicial protection because two judicial remedies are available to the inspected entity: ${ }^{159}$ On the one hand, an indirect challenge, and, on the other hand, an action for damages under Articles 268 and 340 TFEU. However, the Court's position raises some criticisms, as these two remedies fall short in meeting the criteria for full judicial protection analyzed above. ${ }^{160}$

In the case of OLAF, two different types of indirect judicial review can emerge, depending on whether the final measure is adopted by the Commission or by a national authority: In the first case, the Court of Justice can be called to review such acts in the context of an action against the final measure, while, in the second case, the Court can be called upon through a preliminary question of validity under Article 267 TFEU-when and if the sanctioning measure is adopted by the national authority and in the context of a national proceeding against such a measure.

Case law in the context of indirect judicial review against a final act of the Commission shows that the Court has been avoiding calling into question the facts challenged. In the Centre de promotion de l'emploi par la micro-entreprise (CPEM) case, the applicant called into question the procedure followed by OLAF, claiming that the report contained errors of fact and that the right of defense was infringed, as, inter alia, it did not have an opportunity to submit its observations. ${ }^{161}$ However, the Court, arguing that "the rights of the defence are infringed by reason of a procedural irregularity only in so far as the irregularity has a concrete effect on the ability of the undertakings concerned to defend themselves" and that "[c]onsequently, non-compliance with rules in force the purpose of which is to protect the rights of the defense can vitiate the administrative procedure only if it is shown that the latter could have had a different outcome if the rules had been observed," did not examine the claims. ${ }^{162}$ Even though the principle stated by the Court of Justice can be shared-for example, that a procedural irregularity should affect the right of the defense to be taken into account - the use that the Court makes of the principle in this specific case, where the applicant did not have the opportunity to be heard, hence the right of defense had been affected, appears as instrumental to avoiding to review the substance of the case.

The willingness to avoid reviewing the substance of the case can be found not only in the context of an indirect review on a final act of the Commission, but also in a preliminary ruling. In the Thomson Sales Europe SA. case, the applicant challenged the validity of the OLAF investigation. However, the Court concluded for the manifest inadmissibility, as the questions were referred without sufficient information on the factual and legislative context. ${ }^{163}$

\footnotetext{
${ }^{155}$ Tillack, Case T-193/04 at para. 81; Case T-261/09 P, European Comm'n v. Antonello Violetti \& Others, 2010 E.C.R. I00000, para. 73; Inox Mare, Case T-289/16 at paras. 29-30.

${ }^{156}$ Inox Mare, Case T-289/16 at paras. 23-27.

${ }^{157}$ Joined Cases F-5 \& 7/05, Antonello Violetti \& Others v. Comm'n, 2009 FP-I-A-1-00083, para. 94.

${ }^{158}$ Violetti, Case T-261/09 P at para. 62.

${ }^{159}$ Tillack, Case T-193/04 at para. 80.

${ }^{160}$ See Inghelram, supra note 41 , at 622-25.

${ }^{161}$ Case T-444/07, Centre de promotion de l'emploi par la micro-entreprise (CPEM) v. Comm'n, 2009 E.C.R. II-02121, para. 45.

${ }^{162} I d$. at para. 46.

${ }^{163}$ Case C-348/11, Thomson Sales Europe SA v. Administration des douanes (March 23, 2012), http://curia.europa.eu/juris/ liste.jsf?num $=\mathrm{C}-348 / 11$.
} 
The approach of the Court of Justice that emerges in the context of the two indirect remedies raises criticisms for three reasons. First, according to the Court of Strasbourg case law, judicial scrutiny on inspection should review both aspects of fact and questions of law: ${ }^{164}$ Therefore, the tendency of the Court of Luxembourg to avoid reviewing the substance of the case falls short of fulfilling this requirement. Second, both indirect remedies can be activated only if and when the final act is adopted: Therefore, it is doubtful whether they meet the requirements according to which the judicial remedy must be certain and timely. ${ }^{165}$ Third, when the remedy of the preliminary ruling is to be used because the final act is a national one, the applicant is dependent on the preliminary question. Thus, the uncertainty of the remedy depends not only on whether a sanction is adopted on the basis of the inspection, but also on whether the court would examine the claim.

As for the action for damages, it is well known that the Court has consistently stated that the right to compensation for damage depends on three requirements: The rule of law infringed must be intended to confer rights on individuals, the breach must be sufficiently serious, and the existence of a causal connection between that conduct and the damage. ${ }^{166}$ When inspections are concerned, specific problems can arise as for the assessment of each of these requirements.

More specifically, the requirement can lead to compensation only when there is a sufficiently serious breach of a rule of law intended to confer rights upon individuals; in Camos Grau, the violation of the principle of independence during OLAF's investigation has been considered as a breach of a rule intended to confer rights on individuals. ${ }^{167}$ In Franchet \& Byk, the violation of the right of the defense and the principle of the presumption of innocence were also considered as rules intended to confer rights on individuals, while, in the same case, the violation of the duty to give reasons was not considered to raise any liability for the EU institutions. ${ }^{168}$ In the Tillack case, the violation of the principle of sound administration was not, in itself, considered to confer rights upon individuals, "except where it constitutes the expression of specific rights such as the right to have affairs handled impartially, fairly and within a reasonable time, the right to be heard, the right to have access to files, or the obligation to give reasons for decisions." 169

The condition of the existence of a causal connection between that conduct and the alleged damage has also been questioned due to the lack of binding effect of inspection reports. As for OLAF's investigations, in the Tillack case, the Court found no causal link between OLAF's recommendations to national authorities and the harm to the reputation of the inspected party due to the discretionary power of national authorities in deciding whether to follow such recommendations. ${ }^{170}$ That the lack of binding effect of the recommendations excludes the direct causal nexus between the forwarding of information and the damage, and hence the liability of the EU institution, has also been argued by the Civil Service Tribunal in the Violetti case. ${ }^{171}$

The limitations for an inspected entity to successfully file an action for damages are not exclusive to OLAF. One such example can also be found in the food safety area. In the Bowland case, the Food and Veterinary Office (FVO), a directorate within the Health and Consumer Protection DirectorateGeneral (DG) of the Commission, whose competences have now been given to the Directorate F, inspected the firm and found levels of antibiotics in the milk it produced. The findings of FVO were set in an internal note and reflected in the DG final report of the mission conducted in the UK. ${ }^{172}$

\footnotetext{
${ }^{164}$ Ravon, App. No. 18497/03 at para. 29.

${ }^{165}$ Widdershoven \& Craig, supra note 15, at 349. The Civil Service Tribunal, in the Violetti case, also argued that only the action for annulment against the inspections act (and not the final act) provides a timely remedy. Violetti, Joined Cases F-5 \& F-7/05 at para. 78-81. For criticisms, see also Inghelram, supra note 41, at 625-26.

${ }^{166}$ Case C-352/98 P, Bergadermand Goupil v. Comm'n, 2000 E.C.R. I-5291, para. 42.

${ }^{167}$ Camós Grau, Case T-309/03 at paras. 102-03.

${ }^{168}$ Case T-48/05, Yves Franchet \& Daniel Byk v. Comm'n, 2008 E.C.R. II-01585, paras. 156, 217-19.

${ }^{169}$ Tillack, Case T-193/04 at paras. 127-28.

${ }^{170} I d$. at para. 122 .

${ }^{171}$ Violetti, Joined Cases F-5 \& F-7/05 at paras. 125-26.

${ }^{172}$ Case T-212/06, Bowland Dairy Prod. v. Comm'n, 2009 E.C.R. II-04073, para. 5.
} 
The national competent authority, the British Food Standards Agency (FSA), inserted the note in the rapid alert system for the notification of a direct or indirect risk to human health deriving from food. As a result, the firm had to close for ten days. Following a new audit conducted by the FSA, the UK authorities identified new corrective actions and asked the Commission to declare the milk product marketed. After the refusal of the Commission to accept this statement, as they continued to consider that the level of antibiotics in the milk products concerned was not compliant with EU law, and to change the notification in the rapid alert system accordingly, Bowland filed for damages. However, the Court of First Instance stated that, as the Commission's action was not binding upon national authorities, a claim for damages was inadmissible. ${ }^{173}$

The analysis shows that in the second group of cases ex post judicial review of the Court of Justice on inspection conducted by EU authorities falls short of meeting all the features set forth in the case law of the Court of Strasbourg for such review to be considered full and effective: Namely, that such review controls both elements of law and of fact, that it checks both the decision to inspect and the inspecting activities, and that it is timely and certain.

In the case of OLAF's, EFCA's, and Directorate F's inspections, neither of these requirements is met. First, the Court of Justice tends to avoid reviewing the substance of the case. Second, the availability of indirect remedies - a preliminary question of validity when and if the sanctioning measure is adopted by the national authority in the context of a national proceedings against such measure or, in the case OLAF's report is followed by a decision of the Commission, whether there is indirect judicial review against such a final decision - is uncertain, as it depends on whether a final act will be adopted and, in the case of the preliminary ruling, on whether the Court will get to examine the claim. Third, the success of the action for damages against inspections is limited, notably because of the difficulty in proving the causal link between the inspection and the damage, as the results of the inspection do not have a binding effect.

Contrarily, in the first group of cases - which include the competition, banking, financial, and aviation sectors - the right of the inspected party to act for the annulment of the decision to inspect is recognized. The activities that are conducted on the basis of such a decision are generally to be challenged only in the context of an action for the annulment of the final act. According to the Casino and Les Mousquetaires cases, inspecting acts can be challenged together with the decision to inspect, but only if they are capable of affecting the interests of the applicant, and if the inspected party opposes the act that could impair the right to privacy during the inspection procedure so that the Commission's reaction or omission can amount to a reviewable act. The solution according to which an inspecting act can be challenged together with the inspection decision is preferable, as judicial review would take place within a shorter, and hence more reasonable according to Strasbourg parameters, time. Even if the conditions to challenge the inspecting act together with the decision to inspect are extremely restrictive, by opening in principle this possibility, the General Court has increased the protection for the inspected individuals.

The model of judicial review existing in the first group of cases-based on the right to plea for the annulment of the decision to inspect and on the possibility, limited to the restrictive conditions mentioned above, to challenge the inspecting acts together with the decision to inspect-could be extended to inspection in all sectors.

\section{F. Concluding Remarks}

The Court of Justice argued that the lack of ex ante judicial authorization can be counterbalanced through procedural guarantees and ex post judicial control. The Strasbourg Court, however, is much stricter in admitting the possibility of such counterbalance. According to the Strasbourg Court, for ex post judicial review on inspections to be full, several conditions need to be met: a) it shall cover both questions of fact and questions of law, b) it shall permit to challenge both the inspecting decision and the inspecting acts, and c) it must be certain and within a reasonable time limit.

\footnotetext{
${ }^{173} I d$. at paras. $43-44$.
} 
From the point of view of judicial protection, inspection powers of EU authorities need to be divided into two groups. In the first group-comprised of the competition, banking, financial, and aviation section - the action for annulment against the inspecting decision is explicitly provided for. Even though the GC recently argued that the current system of remedies available in the EU fulfills all the requirements set forth by the Court of Strasbourg, it is questionable whether the general rule according to which the activities that are conducted on the basis of the inspection decision are to be challenged only together with the final act comply with the condition according to which remedies should be available to challenge both the inspecting decision and the inspecting acts within a reasonable time limit. In Casino and Les Mousquetaires, however, the GC clarified that inspecting acts can be challenged together with the decision to inspect if two conditions are met: If they are capable of affecting the interests of the applicant, and if the inspected party opposes the act that could impair the right to privacy before such an act takes place, so that a special procedure is opened and the Commission's reaction, or omission, can amount to a final and reviewable act.

In the areas of the protection of financial interests, fisheries, and food safety, the shortcomings of the model of judicial protection are more serious. First, in the lack of an explicit recognition of an action for the annulment of the decision to inspect, the Court of Justice has repeatedly stated that no inspecting activities - decision to inspect, inspection act, inspection report, recommendations following the inspection - can be directly challenged through an action for annulment. According to the Court, the lack of admissibility of the action for annulment against inspections does not infringe the right to effective judicial protection because two judicial remedies are available to the inspected entity: On the one hand, an indirect challenge when the final act is adopted, and, on the other hand, an action for damages. However, the analysis demonstrated that both remedies raise concerns. Indirect remedies - which, in the case of EFCA and Directorate F, always take the form of a preliminary question of validity, while, in the case OLAF's recommendations are directed to EU institutions, can result in an action before the Court of Justice for the annulment of a final act of an EU institution-can be activated only if and when the final act is adopted. This is why they fall short to meet the requirement, set by the Strasbourg Court, according to which the judicial remedy must be certain and timely. As for the action for damages, in several cases, the Court of Justice has argued that, as inspection reports are not binding, no causal link between the inspection and the damage could be proved.

The right to effective judicial protection of the inspected entities vis-à-vis administrative inspections of EU authorities should be improved.

A first remedy - which draws inspiration from a model of judicial protection already existing in the EU legal system - could be to explicitly provide for an action for the annulment of the decision to inspect, like the one existing in the competition, financial, and banking areas, or in other sectors where EU authorities have the power to inspect. The fact that such a remedy also exists in the banking area-where sanctions are not always adopted by the ECB, but also by national banking authorities, according to a complex system of division of competences ${ }^{174}$ _further strengthens the argument that an action for the annulment against the decision to inspect can also be ensured in sectors where there are composite procedures and sanctions are adopted at the national level. In order to activate such action, a clearer formalization of the procedural conditions to conduct inspections is desirable; for example, a formal decision to inspect, instead of an authorization, should be introduced in the sectors where it is currently lacking. ${ }^{175}$ However, as in some cases, the Court of Justice has adopted a substantial approach, recognizing the direct effect on the right of an individual regardless of the formal qualification of an act; ${ }^{176}$ this change could also be done through a shift in the case law of the Court of Justice regarding the acts through which an EU

\footnotetext{
${ }^{174}$ See supra Section B.

${ }^{175}$ See supra Section B.

${ }^{176}$ For instance, Case T-84/97, Bureau Européen des Unions de Consommateurs (BEUC) v. Comm'n, 1998 E.C.R. II 795. For a comment on the substantial approach of the Court of Justice, see Barbara Marchetti, Il sistema integrato di tutela, in L'AMministrazione Europea E LE SUE REgOle, 197-217 (Barbara Marchetti \& Luca De Lucia eds., 2015).
} 
authority orders an inspection, acts that, regardless of their formal qualification, activate an obligation of the inspected entity.

Second, it must be recalled that the system of judicial protection established in the competition, financial, and banking areas, and based on the right to challenge the decision to inspect, but not the inspecting acts, that should generally be challenged with the final sanctioning decision, is not flawless. The reason the Court of Strasbourg insists that both the decision to inspect and the inspecting acts should be challenged in a certain and timely manner-hence, not with the final sanctioning decision-is that harm of the inspected entity's rights can occur immediately during the inspection activity, independent from the eventual adoption of a sanction and that cannot be redressed by simply forbidding the use of the evidence gathered for the adoption of the final sanction. This has long been recognized by the Court of Justice when the legal professional privilege is concerned. ${ }^{177}$ With the recent cases Casino and Les Mousquetaires, in which the privacy of the employees of an undertaking was at stake as during the inspections private emails and other allegedly personal documents were copied, the General Court established a general principle that can open the path for an autonomous and timely challenge of inspecting acts, when such acts are capable of affecting the interests of the applicant. However, in order to activate such a right, the inspected entity has to oppose the inspecting act before it takes place so that a special procedure must be started. ${ }^{178}$ Yet, the features of such a special procedure are not clarified. Moreover, according to the Court, the same limitations apply not only to ask for the annulment of the inspecting act, but also for a second remedy to be activated: The restitution of the documents allegedly impinging on the privacy of the employees of the undertaking was refused on the same grounds. ${ }^{179}$

This point leads to the clear connection between procedural guarantees and judicial control, a link that has been made in the case law both of the Court of Luxembourg and of the Strasbourg Court, and that is crucial for the public interference on fundamental rights to be lawful and proportionate. ${ }^{180}$ Initiatives intended to introduce a common procedure for inspections conducted by EU authorities, applicable horizontally to all sectors, were elaborated by the Research Network on EU Administrative Law (ReNEUAL) ${ }^{181}$ and are at the basis of the proposal for a regulation attached to the Parliamentary Resolution of 9 June $2016 .{ }^{182}$ It is hoped that future developments will take inspiration from these proposals, resulting in a significant improvement of the procedural framework for the inspection powers of EU authorities.

\footnotetext{
${ }^{177}$ Akzo Nobel, Case T-125/103 at para. 87.

${ }^{178}$ Les Mousquetaires, Case T-255/17 at para. 42.

${ }^{179} \mathrm{Id}$. at para. 47.

${ }^{180}$ See supra Section D.

${ }^{181}$ ReNEUAL, Model Rules on EU Administrative Procedure, http://www.reneual.eu/index.php/projects-and-publications/ reneual-1-0.

${ }^{182}$ European Parliament, Resolution of 9 June 2016 for an Open, Effective and Independent European Administration (June 9 , 2016), https://www.europarl.europa.eu/doceo/document/TA-8-2016-0279_EN.pdf. On the genesis of this proposal, see Diana Urania Galetta, Herwig C.H. Hofmann, Oriol Mir Puigpelat \& Jacques Ziller, The Context and Legal Elements of a Proposal for a Regulation on the Administrative Procedure of the European Union's Institutions, Bodies, Offices and Agencies, RIDPC 313 (2016). I compared and analyzed the provisions concerning EU inspections of the Model Rule and of the proposal for Regulation in Maurizia De Bellis, Le ispezioni nei procedimenti europei e la tutela del privato: problemi e prospettive, in I PROCEDIMENTI AMMINISTRATIVI DI ADJUDICATION NELL'UNIONE EUROPEA: PRINCIPI GENERALI E DISCIPLINE SETTORIALI 153 (Giacinto della Cananea \& Martina Conticelli eds., 2017).
}

Cite this article: De Bellis M (2021). Multi-level Administration, Inspections and Fundamental Rights: Is Judicial Protection Full and Effective?. German Law Journal 22, 416-440. https://doi.org/10.1017/glj.2021.14 